\title{
Yeasts associated with the production of distilled alcoholic beverages
}

Graeme M. Walker

Patricia Lappe-Oliveras

Rubén Moreno-Terrazas

Manuel Kirchmayr

Melchor Arellano-Plaza

Anne Christine Gschaedler-Mathis

This is the Author's Accepted Manuscript of a book chapter published by Springer in Yeasts in the Production of Wine.

The final publication is available online from Springer

https://dx.doi.org/10.1007/978-1-4939-9782-4 


\title{
Chapter 16
}

\section{YEASTS ASSOCIATED WITH THE PRODUCTION OF DISTILLED ALCOHOLIC BEVERAGES}

\author{
Graeme M. Walker ${ }^{*}$, Patricia Lappe-Oliveras ${ }^{2}$, Rubén Moreno-Terrazas ${ }^{3}$, \\ Manuel Kirchmayr ${ }^{4}$, Melchor Arellano-Plaza ${ }^{4}$ and Anne Christine Gschaedler- \\ Mathis $^{4}$
}

${ }^{1}$ School of Applied Sciences, Abertay University, Dundee DD1 1HG, Scotland, UK (e-mail: g.walker@abertay.ac.uk, Tel: +44 01382 308658)

${ }^{2}$ Departamento de Botánica, Instituto de Biología, Universidad Nacional Autónoma de México, Av. Universidad 3000, Cd. de México C.P. 04510, México (e-mail: lappe@,ib.unam.mx, Tel: +52 (1) 55 56229166, Fax: +52 (1) 55-551760)

${ }^{3}$ Departamento de Ingenierías Química, de Alimentos e Industrial, Universidad Iberoamericana, Prolongación Paseo de la Reforma 880, Cd. de México C.P. 01219 (e-mail: ruben.moreno@ibero.mx, Tel: +52-(1)55 59504062

${ }^{4}$ Unidad de Biotecnología Industrial, Centro de Investigación y Asistencia en Tecnología y Diseño del Estado de Jalisco A.C. (CIATEJ), Camino Arenero 1227, El Bajío del Arenal, Zapopoan C.P. 45019, Jalisco, México (e-mail mkichmayr@ciatej.mx; marellano@ciatej.mx; agschaedler@ciatej.mx , Tel: +52 (1) 33 455200, Fax: +52 (1) 33455200 Ext 1001

*Corresponding author:

g.walker@abertay.ac.uk

\begin{abstract}
Distilled alcoholic beverages are produced firstly by fermenting sugars emanating from cereal starches (in the case of whiskies), sucrose-rich plants (in the case of rums), fructooligosaccharide-rich plants (in the case of tequila) or from fruits (in the case of brandies). Traditionally, such fermentations were conducted in a spontaneous fashion, relying on indigenous microbiota, including wild yeasts. In modern practices, selected strains of Saccharomyces cerevisiae are employed to produce high levels of ethanol together with numerous secondary metabolites (eg. higher alcohols, esters, carbonyls etc.) which greatly influence the final flavour and aroma characteristics of spirits following distillation of the fermented wash. Therefore, distillers, like winemakers, must carefully choose their yeast strain which will be very important in providing the alcohol content and the sensory profiles of
\end{abstract}


spirit beverages. This Chapter discusses yeast and fermentation aspects associated with the production of selected distilled spirits and highlights similarities and differences with the production of wine.

\section{Table of content:}

\subsection{Introduction}

16.2 Yeasts in production of cereal-based spirits

16.3 Yeasts in the production of Agave and Dasylirion -based spirits

16.3.1 Distilled Agave and Dasylirion spirits: Tequila, mezcal, bacanora, raicilla and sotol

16.3.2 Tequila categories, types and production process

16.3.3 Mezcal, bacanora and sotol categories, types and production Processes

16.3.4 Yeast and fermentation aspects

16.3.5 Recent developments and future prospects

16.4 Yeasts in production of miscellaneous spirits

16.4.1 Yeasts in production of fruit-based spirits

16.4.2 Yeasts in production of sugarcane-based spirits

16.4.3 Yeasts in production of whey-based spirits

16.5 Conclusions \& future prospects

16.6 References

\subsection{Introduction}

The production of alcoholic beverages from fermentable carbon sources by yeast is the oldest and most economically important of all biotechnologies. Yeast, in particular the species Saccharomyces cerevisiae, plays a vital role in the production of all alcoholic beverages (see Figure 16.1) and the selection of suitable yeast strains is essential not only to maximise alcohol yield, but also to enhance beverage sensory quality.

Fig 16.1 here 
The yeast species that dominates in the production of worldwide distilled spirits is $S$. cerevisiae, and the specific strains of this species employed in fermentation exert a profound influence on spirit flavour and aroma characteristics. For large-scale beverage fermentations, as in brewing, winemaking and distilled spirit production, pure cultures of selected strains of $S$. cerevisiae are typically employed (Walker 1998). These strains are either sourced and cultivated in house or supplied for direct inoculation from yeast producing companies. In smaller-scale (artisanal) processes, spontaneous fermentations may be allowed to occur that rely on indigenous microorganisms (wild yeasts and bacteria) present in the raw materials and in the production facility. For example, this would be typical in small distilleries in Mexico (for Tequila and Mezcal production) and in Brazil (for Cachaça production). In some types of alcoholic beverage fermentations, non-S. cerevisiae yeasts may be employed either as starter cultures, or occur naturally. For example, Schizosaccharomyces pombe is found in molasses fermentations for rum production, and Kluyveromyces marxianus strains are employed in cheese whey fermentations for the production of white spirits such as vodka and gin. Table 16.1 summarizes different yeast species encountered in alcoholic beverage fermentations.

Table 16.1 here

This Chapter will focus on the zymology aspects pertaining to distilled spirit production and will compare and contrast fermentation processes for both wine and spirits.

\subsection{Yeasts in production of cereal-based spirits}


Distilled spirits that employ cereals as their starting raw materials include: whisky (e.g. Scotch whisky), whiskey (e.g. Irish and American), vodka, gin and shochu (see Table 16.1). The cereals in question are predominantly barely, wheat, rye, maize, rice and sorghum. The starting carbohydrate in all cases is starch which cannot be fermented directly by $S$. cerevisiae. This glucose polysaccharide requires prehydrolysis to simple sugars prior to yeast fermentation, and this contrasts markedly from winemaking where fermentable sugars (glucose and fructose) are readily available in the grape berries and in the subsequent must. Other salient differences exist between wine and distilled cereal spirits. For example, the alcohol content of bottled spirits is approximately 3-4 fold higher in finished wines (e.g. a typical whisky would have an alcohol concentration of $40 \% \mathrm{v} / \mathrm{v}$, whereas a typical table wine would be $12 \% \mathrm{v} / \mathrm{v})$. Yeast strains employed for spirits and for wine are also different and the following discussion covers fermentation aspects of distilled spirits from cereals, with a special emphasis on whisky production processes. Figure 16.2 outlines the major categories of global whiskies.

Fig 16.2 here

One of the best selling spirit drinks in the world is Scotch whisky which is produced by fermentation of an infusion of malted barley and other cereals with strains of $S$. cerevisiae and matured over time in oak barrels (Russell and Stewart 2014; Walker and Hill 2016). There are two main types of Scotch whisky: malt whisky and grain whisky. Blended Scotch whisky is a mix of these types. Malt whisky is produced using malted barley as the cereal and enzyme source, and the fermented wash is distilled in copper pot stills. Grain whisky is produced using wheat or maize as the 
predominant cereal, with a small proportion (e.g. 15\%) of malted barely as a source of amylolytic enzymes, and the fermented wash is distilled continuously in large "Patent" or "Coffey" stills. In the UK, Scotch Whisky has had a legal definition since 1909 (recognised by the EC in 1989) and the current (2009) Scotch Whisky Regulations define five categories of Scotch Whisky: Single Malt, Single Grain, Blended, Blended Malt and Blended Grain. Blended Scotch whisky is typically a mix of malt and grain whiskies, with some blends having a much a 50 individual malt and grain whiskies. These Regulations state that "Scotch Whisky":

a. Has been distilled at a distillery in Scotland from water and malted barley (to which only whole grains of other cereals have been added) all of which have been -

(i) processed at that distillery into a mash;

(ii) converted at that distillery into a fermentable substrate only by endogenous enzyme systems; and

(iii) fermented at that distillery only by the addition of yeast;

b. Has been distilled at an alcoholic strength by volume of less than $94.8 \%$.

c. Has been matured in oak casks not exceeding 700 litres for a period not less than 3 years.

Whisky processes involve the production of a sugary solution called wort, which is generated following the enzymatic extraction of maltose and other sugars from an aqueous mash of barley malt grist (as in the case of malt whisky) or an aqueous mash of malt and other cereals (as in the case of grain whisky). The saccharification of cereal starch is accomplished by amylolytic enzymes present in malted barely. For Scotch whisky production, exogenous (commercial) enzymes are not permitted, but for grain neutral spirit (GNS) destined for vodka or gin production, application of such enzymes is permitted. After cooling, the wort is then fermented with selected strains of $S$. cerevisiae to produce wash at around $8 \% \mathrm{v} / \mathrm{v}$ ethanol. For malt whisky, 
fresh alcohol distillate is produced following two batch distillations as shown in Fig 16.3 .

Fig 16.3 here

The spirit fraction typically has an alcohol concentration of $63-70 \% \mathrm{v} / \mathrm{v}$ and is matured in oak barrels for a minimum of 3 years (but often for 10-15 years) to impart characteristic flavour, aroma and taste to the spirit (Russell and Stewart 2014; Bryce and Stewart 2004; Murray 2017). "Single malt" Scotch whisky is such whisky produced only from malted barley and from a single distillery. Grain whisky distillations employ continuous Coffey (or Patent) stills comprising a rectifier and an analyser to produce spirit at a strength of $94.5 \% \mathrm{v} / \mathrm{v}$ alcohol. Grain whiskies are mainly used for blending with malt whiskies (Lea and Piggott 2003).

Regarding the yeasts used for whisky production, fermentations are conducted by specific strains of $S$. cerevisiae which convert mash sugars into ethanol, carbon dioxide and numerous secondary fermentation metabolites that collectively act as flavour congeners in the final spirit (Walker and Hill 2016). Yeast strain selection for whisky production is therefore critically important in dictating the organoleptic qualities of the final product. The same is true for wine yeasts. The fermentable sugars extracted following cereal mashing are predominantly maltose and maltotriose, in contrast to glucose, fructose and sucrose in wine musts. An important distinction between beer and whisky production is that in whisky wort preparation, because the wort is not boiled, starch degradation processes do not stop when the wort leaves the mashing vessel. Consequently, residual malt enzymes continue their amylolytic activity in fermentation. This has similarities with the Simultaneous Saccharification 
and Fermentation (SSF) processes typically found in fuel alcohol plants that process maize (Walker 2011).

In Scotch whisky processes, where no exogenous enzymes are allowed, maltodextrin molecules (small branched oligosaccharides) in the wort may be utilised by some whisky yeast strains. For example, a widely used Scotch whisky yeast strain, named "M type" (thought to be a hybrid of $S$. cerevisiae and $S$. cerevisiae var diastaticus) possesses limited starch-debranching amylolytic activity (Watson 1993). Whisky yeast strains have been described as "maltose + oligosaccharide type" to reflect their properties in rapidly fermenting maltose, maltotriose and other oligosaccharides. In contrast, other beverage yeasts have been described as "sucrose + maltose type" to reflect fermentation of sucrose, glucose and maltose (Jones 1998). The ability to efficiently and completely ferment maltotriose is an important distinguishing characteristic of Scotch whisky yeasts. Table 16.2 outlines the main desired attributes of distiller's yeast, compared with wine yeasts.

Table 16.2 here

Spontaneous fermentations are no longer conducted in modern whisky distilleries that use freshly propagated or commercially supplied pure-cultured strains of $S$. cerevisiae. This yeast may be supplied in compressed (cake) form, liquid (cream) yeast, or in dried form (Walker and Hill 2016). The pitching rate (inoculum) is generally $0.5-2 \times 10^{7}$ cells $/ \mathrm{mL}$. Unlike breweries or wineries, whisky fermentations are typically allowed to proceed for 2-3days without precise temperature control. Wort $\mathrm{pH}$ in a whisky fermentation will start at $\mathrm{pH} 5-5.5$ and will fall to $\mathrm{pH} 4.2-4.5$ at the end of fermentation. Yeast viability at the end of fermentation is very low due to the 
combination of low $\mathrm{pH}$, temperatures $>30^{\circ} \mathrm{C}$, and high final ethanol concentrations. These factors exert considerable physiological stress on yeast (Walker and van Dijck 2006).

Whisky-distillers (and oenologists), unlike brewers, do not recycle yeast. Fermented wash including yeast is distilled resulting with concomitant destruction of yeast cells. This necessitates the supply of freshly propagated yeast from separate commercial yeast organisations (Jones 1998). The specifications for Scotch whisky yeast strains include yeast cell viability, bacterial count and moisture content. (Korhola et al. 1989). Some Scotch whisky distilleries formerly supplemented their distiller's yeast with a small proportion of spent brewer's yeast. The presence of brewers' yeast provides flavour benefits in terms of final spirit quality (Korhola et al., 1989) and in controlling fermentation $\mathrm{pH}$ due to pyruvic acid uptake (McGill 1990).

In addition to the selected distillers strain of yeast to initiate fermentation, various wild yeasts such as non-distilling strains of $S$. cerevisiae, Pichia membranefaciens, Torulaspora delbrueckii and Candida species may also be present in whisky fermentations. Although such yeasts are potentially problematic in affecting fermentation progress, their levels are usually kept low due to the dominance of the main production yeast strain of $S$. cerevisiae. Another wild yeast, Dekkera bruxellensis (anamorph Brettanomyces bruxellensis), which is a common contaminant in wine fermentations, may play an important role in cereal fermentations for distilled spirits production. For example, Passoth et al. (2007) found that D. bruxellensis dominated wheat-based distillery fermentations following out-competition of the $S$. cerevisiae starter cultures.

Due to the lack of a pre-fermentation boiling stage (as in brewing) and due to the nonaseptic processes employed, other microorganisms, notably bacteria, are present 
during cereal fermentations. For example, the importance of lactic acid bacteria has been shown in grain whisky processes (van Beek and Priest 2003); in wheat-based processes (Passoth et al. 2007); in corn mash-processes (Thomas et al. 2001; Smith 2017) and in rice-based processes (Watanabe et al. 2007). In a wheat distillery, Passoth et al. (2007) proposed that Lactobacillus vini contributed, with yeast, to an "ethanol-producing consortium". In Scotch malt whisky fermentations, limited bacterial activity plays an important role in flavour development of the final spirit. In particular, whisky producers recognise positive influences of lactic acid bacteria including Lactobacillus plantarum and L. fermentum during the latter stages of fermentation. Lactic acid bacteria (LAB) can produce lactic and acetic acids, which become esterified to ethyl lactate and ethyl acetate, respectively. These compounds impart sweet, fruity, creamy, and pineapple-like flavours to the spirit. Lactobacillus spp. can also produce $\gamma$-dodecalactone which imparts a "sweet and fatty" characteristic to the spirit. In other cereal-based distilled spirits such as "sour-mash" bourbons, lactic acid bacterial growth is encouraged during certain process steps to depress wort $\mathrm{pH}$ and impart desired flavour congeners to the final distillate (Smith 2017).

The choice of the distillers strain, together with contributions from other microorganisms, will play an important role in dictating the final flavour and aroma characteristics of cereal-based distilled spirits. In addition to the main fermentation metabolites, ethanol and carbon dioxide, numerous secondary fermentation compounds will be produced that act as important flavour congeners in the final spirit. Table 16.3 summarises the principal flavour congeners in distilled spirits, and these include: fatty acids and their esters (e.g. ethyl caprate, ethyl laurate), organic acids 
(e.g. succinic acid), higher alcohols or "fusel oils" (e.g. n-propanol, isoamylalcohol), aldehydes (e.g. acetaldehyde) and vicinal diketones (diacetyl).

Table 16.3 here

Many flavour-active compounds are produced by yeast in reactions between alcohols and acyl CoA molecules but some esters, notably ethyl lactate, are linked to the presence of lactic acid bacteria. Ester production during fermentation is linked to the relative abundance of the corresponding alcohols and acyl CoAs, with ethyl acetate being the predominant ester produced, with isoamyl acetate at lower concentrations. The latter has a much lower flavour threshold than ethyl acetate and contributes a fruity (banana) aroma to beverages. Another yeast-derived group of flavour congeners important in distilled spirits (and in wine) are the fusel oils. Their concentration levels in beverages are linked to the levels of corresponding amino acids in the fermentation medium (for example, phenylalanine stimulates phenylethanol production leading to a rose-like aroma). In distilled spirits these compounds, if controlled within certain limits, are beneficial contributors to the aroma characteristics of distillates.

Further information on the origin of different flavour congeners in distilled spirits can be found in: Lea and Piggott (2003), Walker and Hughes (2010), Russell and Stewart (2014), Goodall et al. (2015) and Walker et al. (2017).

\subsection{Yeasts in the production of Agave and and Dasylirion-based spirits}

Agaves or magueyes (Agave) and sotoles (Dasylirion) are succulent plants that have great biological, ecological and economic importance. They belong to the family 
Asparagaceae, subfamilies Agavoideae and Nolinoideae, respectively, which are endemic to America. During pre-Hispanic times the integral use of these plants was so important, that the survival and cultural development of several Mesoamerican civilizations could not be explained without their existence (Fiore et al. 2005; LappeOliveras et al. 2008). Different Agave and Dasylirion species have long been exploited for the production of distilled alcoholic beverages, which are produced by distillation of the fermented must of several species, and are generically known with the names mezcal or sotol, respectively (Lappe-Oliveras et al. 2008).

In Mexico, a great diversity of agaves (175 species) exists with around 50 species being used in the production of mezcal. From these, 28 are frequently employed in artisanal production and, 14 in larger-scale commercial processes. The final product may come from the exploitation of a single agave species, or from the combination of several ones (Aguirre and Eguiarte 2013; Torres et al. 2015). Thus, the distinctive characteristics of mezcal spirit beverages depends on: the agave species or mixture of species used; the growth conditions and maturity of the plants, as well as from the cooking, fermentation, distillation and aging processes. Together, these factors give rise to a great diversity of mezcales. Some of them, such as tequila, bacanora and mezcal, are widely known, have national and international recognition and are protected by their appellation of origin (AO). However, most mezcales are regional products, not known outside their place of origin and do not have an $\mathrm{AO}$ that protects them.

The genus Dasylirion consists of 20 species, 16 of them endemic, which grow in several states of Mexico (Reyes-Valdes et al. 2012). Sotol is produced in the states of Chihuahua, Coahuila and Durango from several Dasylirion species, mainly $D$. durangense. 


\subsubsection{Distilled Agave spirits: Tequila, mezcal, bacanora, raicilla and sotol}

Tequila, Mezcal, Bacanora, Raicilla and sotol are specific names of distilled beverages obtained from different Agave and Dasylirion species (Table 16.4). Tequila is the famous spirit beverage classically associated with Mexico. The word tequila derives from the Nahuatl tequillan, from tequitl = tribute, work or employment and tlan $=$ place, meaning a place of tribute or in which work is done. However, this word may also be associated with the Ticuilas a tribe who lived in the hillside of the extinct volcano Tequila, in Jalisco. The word mezcal, mescal or mexcal derives from the Nahuatl words $m e t l=$ maguey or agave, and ixcaloa $=$ to roast, and means roasted agave. In pre-Hispanic Mexico the agave plants had several uses (food, fodder, medicine, construction material, textiles, and soap, among others) and for centuries they have been used to produce alcoholic beverages.

Table 16.4 here

With the introduction by the Spaniards of the Philippine and Arab stills, in the second half of the sixteenth and the beginning of the seventeenth centuries, respectively, the distilled agave beverages originated and over time took their present form (Cedeño, 2003). However, recently some researchers based on strong archaeological and ethnographic evidence have proposed that distillation is not of mestizo origin, but prehispanic, which has caused great controversy that remains to be elucidated.

The following contribution will present the different processes of elaboration of agave spirits with special emphasis on yeasts species and their contribution to the characteristics of the final product. 


\subsubsection{Tequila categories, types and production process}

The most famous agave spirit from Mexico is undoubtedly Tequila. This alcoholic beverage is obtained from distillation of the fermented must of Agave tequilana Weber var. azul; it is produced in the territory of $\mathrm{AO}$ which includes all the state of Jalisco and some regions of the states of Guanajuato, Michoacán, Nayarit and Tamaulipas (Table 16.4). The principal characteristics of this agave are: a high concentration of a complex mixture of highly branched fructooligosaccharides containing principally $\beta$ (2-1) linkages (Mancilla-Margalli and López 2006) which are used as reserve carbohydrate by the plant, low fiber content, and the presence of some chemical compounds like terpenes, which contribute to the flavour and taste of the final product. The elaboration process is subject to the Mexican Official Regulation NOM-006-SCFI-2012, which recognizes only two tequila categories: "Tequila 100\%" obtained exclusively from sugars of A. tequilana var. azul, and "Tequila", produced using $51 \%$ of agave sugars and $49 \%$ from other sugar sources (sugar cane, molasses or hydrolyzed corn syrup). In each category there are five types of tequila: tequila blanco (silver) without maturation; tequila joven or oro (gold) containing permitted additives (oak extract, glycerin, sugar syrup) and colours (generally caramel colour); tequila reposado (aged) matured at least two months in white oak barrels (this being the most popular kind of tequila); tequila añejo (extra aged) and tequila extra añejo (ultra aged) matured for 1 or 3 years in white oak barrels, respectively. According to the Consejo Regulador del Tequila (CRT) (Tequila Regulatory Council) in 2017 the global production of tequila was 271.4 million liters. "Tequila 100\%" represented more than $56 \%$ of the total production, and more than $80 \%$ of the annual production was exported. By mid-2018 there were 1450 registered tequila brands produced in 
235 Mexican distilleries certified by the CRT, which is the council that verifies the compliance of the Official Mexican Regulation.

The process of elaboration begins with the harvest of 7 to 9 year old agave plants (Cedeño, 2003). As with many other agave plants, A. tequilana var. azul is rich in carbohydrates, mainly highly branched fructans and neo-fructans (Mancilla-Margalli and López 2006; Waleckx et al. 2008). The complete plant is cut down, the leaves are removed leaving the stem and the leaf bases, what is called the head or piña. The heads are cooked in brick ovens heated by steam injection for $36-48 \mathrm{~h}$ at $100^{\circ} \mathrm{C}$; then the steam injection is suspended and the agave pieces are left in the oven for two more days to complete the cooking process. Nowadays, in most distilleries, brick ovens have been replaced by steel autoclaves to increase efficiency. The main objectives of the cooking process are: 1) To accomplish hydrolysis of fructans into simple sugars, mainly fructose, glucose and sucrose, which are easily fermented by yeasts; 2) To facilitate the milling operation and the extraction of sugars, since during cooking the agave plants acquire a soft texture 3) To generate some important chemical compounds (e.g. fusel oils) which determine the sensorial characteristics of the final product; some of these are produced by caramelisation and Maillard reactions (Cedeño 2003).

The cooked agave is milled to extract a sweet must which contains a high concentration of fructose and other fermentable sugars. In some distilleries, the milling process is still done with rudimentary mills (tahona), such as those used in the elaboration of mezcal. Nowadays, the mills used in the tequila industry are similar to those used in the sugarcane industry. In the last 15 years a new milling/cooking technology has been developed to extract fructans or fructose with hot water using 
diffusors. This technology is applied to crude crushed agave or to wash the agave fibers improving the efficiency of the sugar extraction.

The fermentation process will be discussed in detail in the Section 16.3.4. Most distilleries use stainless steel fermentation tanks (whose capacity ranges from 2,000 to $120,000 \mathrm{~L})$ although some still employ wooden tanks. The fermentation wort of "Tequila $100 \% "$ is comprised solely of agave must, with an initial sugar concentration between $4-10 \% \mathrm{v} / \mathrm{v}$, depending on the amount of water added during milling. For "Tequila" other sugars are added, which are previously dissolved and mixed with the agave must to obtain an initial sugar concentration of $8-16 \%$, depending on the sugar tolerance of the yeast strain that will be used in the fermentation process. The $\mathrm{pH}$ of agave must oscillates around 4.5, needing no adjustment. Wort formulation is based on the composition of raw materials and the nutritional requirements for yeast growth and fermentation. Generally, a nitrogen source (urea, ammonium sulphate, ammonium phosphate) and salts (magnesium sulphate) can be added. The fermentation wort may be left to ferment spontaneously or in some distilleries selected S. cerevisiae strains are employed (Gschaedler et al. 2004).

Distillation involves the separation and concentration of the alcohol from the fermented wort. Tequila is obtained after two consecutive differential distillations in copper or stainless steel stills. Some distilleries also use rectification columns. During the first distillation the fermented must is split into three different products: a light product (head), a tail product (or vinasses) which is discarded and a slop cut product called ordinario (with an ethanol content of $20-30 \% \mathrm{v} / \mathrm{v}$ ) which is subjected to a second distillation to obtain a distillate or spirit with around 55\% v/v ethanol (Prado Ramirez et al. 2005). 
Finally, Tequila can be matured in different ways, depending on the type of tequila to be obtained. According to the norm, this process can only be carried out in the region of AO. The regulation specifies that the maturation tanks have to be made of oak or holm oak wood with a maximum capacity of $600 \mathrm{~L}$. Prior to bottling, Tequila is filtered. In the case of "Tequila 100\%" the product has to be bottled in the region of $\mathrm{AO}$, "Tequila" can be exported in bulk outside of Mexico, but when bottled, it must be labelled with the legend Made in Mexico or Product of Mexico.

\subsubsection{Mezcal, Bacanora and Sotol categories, types and production process}

For the elaboration of others spirits obtained from Agave and Dasylirion species, the general stages of the processes are the same as in Tequila. The main differences between Tequila and the different types of Mezcal are the species of agave used as raw material, and that the elaboration process of Mezcal is more artisanal than the Tequila process. It is important to highlight that the word mezcal is the generic name of all the agave distilled beverages, which are produced in 26 of the 32 states of Mexico (Aguirre and Eguiarte 2013; Torres et al. 2015). This word refers also to a spirit with $\mathrm{AO}$ whose elaboration process is subjected to the Mexican Official Regulation NOM-070-SCFI-2016). The region of AO includes the states of Durango, Guerrero, Oaxaca, San Luis Potosi, Zacatecas and some regions of Guanajuato, Michoacán, Puebla and Tamaulipas (Table 16.4). The regulation stipulates that mezcal is a distilled alcoholic beverage, $100 \%$ maguey or agave obtained by distillation of the fermented juices, extracted from mature cooked heads of different agave species (A. angustifolia, A. cupreata, A. durangensis, A. inaequidens, A. maximiliana, A. potatorum, A. salmiana, among others) (Fig. 16.4a) harvested in the 
territory of AO. Three categories are recognized Mezcal, Mezcal Artesanal (Artisanal Mezcal) and Mezcal Ancestral (Ancestral Mezcal); each one with six classes.

i) Blanco o joven (white or young), without any further processing

ii) Madurado en vidrio (matured in glass); Mezcal stabilized in a glass container for more than 12 months

iii) Reposado (aged); matured from 2 to 12 months in wooden containers of any size, form and capacity

iv) Añejo (extra aged); matured more than 12 months in wooden containers with less than 1000 L capacity

v) Abocado con (doomed with); added with authorized ingredients to give flavour, such as maguey's worm, damiana, lemon, honey, orange, among others

vi) Destilado con (distilled with); Mezcal must be distilled with ingredients to incorporate flavours, such as turkey or chicken breast, rabbit, mole, fruits, among others

Fig 16.4 here

In 2017 the global production of mezcal reported by the Consejo Regulador del Mezcal was 3,986,221 L, $88 \%$ of Mezcal Artesanal, with Oaxaca being the largest producer $(87.0 \%)$. In recent years Mezcal has achieved national and international recognition, and is the second most consumed agave distilled beverage in the country after Tequila.

Bacanora and sotol are other agave spirits with government official recognition and AO. The Mexican Official Regulation NOM-168-SCFI-2004 specifies that Bacanora 
is only produced in the state of Sonora from A. angustifolia. Sotol is produced in the states of Chihuahua, Coahuila and Durango. The Mexican regulation NOM-159SCFI-2004 recognized two categories: "Sotol 100\% puro", obtained exclusively from sugars of the Dasylirion spp. and "Sotol 51\% or sotol", produced using 51\% of Dasylirion sugars and 49\% from other sugar sources. Four types of Bacanora and Sotol are allowed: blanco (silver), joven u oro (gold), reposado (aged) and añejo (extra aged) with the same description as the different tequila types.

Outside these areas with AO other agave spirits are produced. Raicilla is elaborated in the Western region of Jalisco with different agave species; another spirit is produced in Southern Jalisco with different varieties of $A$. angustifolia.

After harvest of the raw material (wild or cultivated) the mezcal elaboration process is similar to the one described for tequila, although there are modifications since in general it is a more artisanal process (Fig. 16.4). The raw agave heads (Fig. 16.4b) are usually cooked in pit ovens filled with stones, heated with wood and covered with earth, to impart a smoked flavour to the product, or it can be done in brick ovens or steel autoclaves, as in some distilleries of San Luis Potosí and Zacatecas (Figs. 16.4c, 16.4d). The milling of the cooked agave heads is commonly done in a rudimentary mill or tahona (Figs. 16.4e, 16.4f). In San Luis Potosí during the milling process water is added, and the juices are collected by gravity. In Oaxaca and Guerrero all the crushed agave is used in the fermentation process added with some water. In some parts of Guerrero and Michoacán milling is still carried out with wood or steel mallets and the juices are collected in a canoa, a hollow-log fermentation container (Kirchmayr et al. 2017).

A wide variety of fermentation vessels are used: round holes carved directly in the ground, rectangular wooden crates buried in the ground, wooden vats with $1,000 \mathrm{~L}$ 
capacity (Fig. 16.4g), rectangular stone or brick tanks with 3,000-10,000 L capacity (Fig. 16.4h), or stainless steel tanks as those used in the Tequila industry. In general, the fermentation process is carried out spontaneously with the microbiota present in the must, and lasts 1 to 10 days depending on the temperature, region and weather conditions. The fermented must is distillated twice in rudimentary equipment as Philippine-type stills (whose advantage is that they allow the production of spirits from a small amount of agave, and that they can be disassembled and transported quickly) or metal stills (Fig. 16.4i). In others distilleries the classic Arab-type still with serpentine is used (Fig. 16.4j).

\subsubsection{Yeasts and fermentation aspects}

\section{Yeasts identified in natural fermentations}

Few research papers deal with the identification and characterization of the yeasts involved in the fermentation process of the different agave spirits. Lachance (1995) firstly reported the yeast communities present in a Tequila distillery, where a natural fermentation was undertaken. Due to the cooking step carried out to hydrolyse fructans into fermentable sugars, the yeasts found on fresh agave plants (Clavispora lusitaniae, Kluyveromyces marxianus, Metschnikowia agaves, and Pichia membranifaciens) differed from those found on cooked agave, fresh must and crushing equipment (Candida spp., Hanseniaspora vineae, P. membranifaciens, $S$. cerevisiae and Torulaspora delbrueckii). During fermentation, a succession of different yeast species was observed. During earlier fermentation stages a rich mixture of species was detected including Dekkera bruxellensis, Hanseniaspora guilliermondii, H. vinae, $K$. marxianus, P. membranifaciens, $T$. delbrueckii as secondary yeasts and, $S$. cerevisiae (three biotypes) as dominant species. During the progression of the fermentation the heterogeneity of species diminished and, at the 
end of the fermentation the maltose-positive non-flocculent $S$. cerevisiae biotype became dominant (Table 16.4). Gschaedler et al. (2004) reported the isolation of different yeast species in 13 tequila distilleries: Candida magnoliae, Hanseniaspora uvarum, H. vinae Issatchenkia orientalis and Kluyveromyces lactis (Table 16.4). Karyotype analysis of seven S.cerevisae isolates showed six different profiles indicating the existence of a wide genetic heterogeneity within this species (Table $16.3)$.

For Mezcal, studies have been published dealing with the mycobiota present during the natural fermentation stage in different production regions of Mexico. A great diversity of yeasts was found in all studies, especially in the initial fermentation stages, where several common genera and species were recognized (Table 16.4). For example, in mezcal from Yucatán, Lappe et al. (2004) reported Candida parapsilosis, Cl. lusitaniae, Debaryomyces hansenii, I. orientalis, K. marxianus, Millierozyma farinosa, Meyerozyma caribbica, My. guilliermondii, Ogataea angusta, P. membranifaciens, Rhodotorula spp., Rh. mucilaginosa, $T$. delbrueckii and Wickerhanomyces anomalus at the beginning of the fermentation. As fermentation progressed they also observed a dramatic reduction in yeast heterogeneity, probably due to the fermentation conditions, until the end of the fermentation, stage in which $K$. marxianus was the dominant species. During fermentation of Mezcal from Oaxaca, Andrade-Meneses and Ruiz-Terán (2004) identified species of the genera Candida, Hanseniaspora, Rhodotorula and Saccharomyces. In two other mezcal factories from the same region, Kirchmayr et al. (2017) reported a great diversity of nonSaccharomyces species, stating great differences in yeast diversity between factories and production years (Table 16.4). In this study, the coexistence of non- 
Saccharomyces populations (Kluyveromyces, Torulaspora and Zygosaccharomyces) with $S$. cerevisiae until the end of fermentation was described.

In two studies of mezcal from San Luis Potosí produced with A. salmiana subsp. crassispina, a low yeast diversity was detected during fermentation. EscalanteMinakata et al. (2008) identified the yeasts Cl. lusitaniae, K. marxianus and Pichia fermentans; and the bacteria Zymomonas mobilis subsp. mobilis, Z. mobilis subsp. pomaceae, Weissella cibaria, W. paramesenteroides, Lactobacillus farraginis, L. kefiri, L. plantarum and L. pontis, highlighting the participation of a mixed microbial culture in Mezcal fermentations. Verdugo-Valdez et al. (2011) described species of four additional yeast genera (Candida, Kazachstania, Saccharomyces, Torulaspora and Zygosaccharomyces) (Table.16.4). As the presence of growth inhibitors (e.g. saponines) has been reported in the agave species used in this region, the raw material might have a direct impact on the presence and survival of some yeast species. In mezcal from Tamaulipas, species of non-Saccharomyces (Candida, Clavispora, Kluyveromyces, Meyerozyma, Pichia, Torulaspora, Yamadazyma, Zygosaccharomyces) and Saccharomyces (S. cerevisiae) were detected in the early stages of the fermentation (Table 16.4). Only T. delbrueckii and S. cerevisiae persisted until the end of the process.

In two Mezcal distilleries from Durango, Páez-Lerma et al. (2013) identified the same yeast biota (H. uvarum, $K$. marxianus, P. fermentans, $S$. cerevisiae, Saturnispora diversa and $T$. delbrueckii) at the beginning of the fermentation. As fermentation progressed the yeast diversity decreased and at the end of both processes only $S$. cerevisiae or $S$. cerevisiae and $T$. delbrueckii were recovered, respectively.

Kirchmayr et al. (2014) described the microbial consortia found in three mezcal distilleries in Michoacán. Besides species of the genera Kazachstania, 
Kluyveromyces, Meyerozyma, Pichia, Saccharomyces, Torulaspora and Zygosaccharomyces) which changed clearly between factories the authors also described the presence of high populations of lactic acid bacteria during these fermentations (Table 16.4).

In fact, the high abundance of bacterial populations has been detected in several of the mentioned studies, e.g. Tequila and Mezcal from San Luis Potosí, Oaxaca, Guerrero and Tamaulipas, in which different species of Lactobacillus, Leuconostoc, Oenococcus and Weissella, as well as acetic acid bacteria have been reported. Acid fermentation has been observed parallel to the alcoholic fermentation carried out mainly by yeasts and in some cases also by Zymomonas mobilis (Escalante Minakata et al. 2008; Narváez-Zapata et al. 2010, Kirchmayr et al. 2017).

For Bacanora, S. cerevisiae was reported as the predominant yeast during natural fermentation processes carried out in different municipalities, although several nonSaccharomyces yeasts species of the genera Candida, Dekkera, Meyerozyma, Millerozyma, Ogataea, Torulaspora and Rhodotorula were also identified (Table 16.4). For Raicilla and Sotol, few studies have been conducted to characterize the microbial diversity present during fermentation. In both beverages, $K$. marxianus and S. cerevisiae have been reported, in addition to $C l$. lusitania for the former and, Dekkera spp., Kloeckera sp., Hanseniaspora sp., Zygosaccharomyces spp. for the latter.

It is clear that during the initial phases of the fermentation of agave distillates from different regions of Mexico, a great yeasts diversity is present that influences the quality and sensory properties of the final product. Yeast diversity tends to diminish towards the end, as also shown in other spirits and in wine fermentations, although several non-Saccharomyces yeasts persist during the whole process. Besides $S$. 
cerevisiae, the dominant and persistent species, $K$. marxianus and $T$. delbrueckii were reported in most of the aforementioned studies; while $\mathrm{Cl}$. lusitaniae, $\mathrm{M}$. guilliermondii, P. membranifaciens and Z. bailii only in some The remaining yeast genera and species were only sporadically isolated. It is clear that the yeast species involved in agave must spontaneous fermentations are variable, and no Mezcal has the same microbial diversity profile, which makes these beverages unique.

\section{Fermentation development}

The general practice in the production of Mezcal, Raicilla, Bacanora and Sotol is the spontaneous or natural fermentation of the must by the microbiota present in the substrate. In the Tequila industry, few companies maintain the natural fermentation because the microbial consortium produces a wide diversity of volatile compounds that contribute to the sprit flavour and bouquet, despite the lower productivity of ethanol. In some distilleries, mainly in the Tequila industry, the wort is inoculated with $S$. cerevisiae commercial strains (fresh baker's yeasts or dried yeast for wine, beer, or rum production). This practice is not the most appropriate because these yeasts are adapted to other substrates different from agave must and could have a negative impact on the sensory profiles of the final product. Another option is to use yeast strains isolated from natural fermentations which is deemed the most appropriate practice (Gschaedler et al. 2015). When a starter culture inoculum is used, the selected yeast strain (maintained on agar slants, lyophilized or in liquid nitrogen) is propagated in a medium with the same composition as the agave wort. The inoculum is scaled up with continuous aeration to produce enough volume to inoculate 5 or $10 \%$ of the final volume of the fermentation tank. Depending on the yeast strain, populations from $100-300 \times 10^{6}$ cells $\mathrm{mL}^{-1}$ are normally achieved at the 
onset of fermentation (Cedeño 2003). Tequila fermentation starts when the formulated must is poured in the fermentation tanks with or without yeast inoculation. Normally the temperature of the wort at the beginning of the fermentation is around $30^{\circ} \mathrm{C}$, increasing during the process and can exceed $40^{\circ} \mathrm{C}$. This has a negative effect on the yeasts, so the strains employed in the process require to be temperature tolerant. Using yeast inocula, the fermentation time ranges from $12 \mathrm{~h}$ in the fastest process to three or four days in the slowest. Without inocula the fermentation lasts from two days to one week. The time of fermentation has an important impact on the generation of the volatile compounds - these are lower in a fast fermentation compared with a slow fermentation. The rate of the fermentation depends mainly on the yeast strain, medium composition (sugar concentration at the beginning of the fermentation, nutriment supplementation), operating and weather conditions. Ethanol production can be detected from the beginning of the fermentation and, depending on the yeasts involved and the initial sugar concentration, ethanol concentrations reach $4-9 \% \mathrm{v} / \mathrm{v}$ at the end of the process (Gschaedler et al. 2015). In order to increase fermentation yields, the use of enzymes to convert residual agave polymers into fermentable sugars has been reported (Cedeño, 2003). Arrizon and Gschaedler (2002) showed the possibility to achieve high fermentation efficiency (above 90\%) at high initial sugar concentration or when an additional nitrogen source is added during the exponential growth phase of the yeast.

Several studies have focused on the use of non-Saccharomyces yeasts (alone or in coculture with Saccharomyces). Díaz-Montano et al. (2008) compared, at laboratory scale, the fermenting behaviour in A. tequilana juice of 5 yeasts strains: 3 of $S$. cerevisiae and 2 of Hanseniaspora. This study highlighted major differences between the three $S$. cerevisiae strains, especially in the production of volatile compounds, and 
the disadvantage of Hanseniaspora strains to achieve complete alcoholic fermentation, although these strains produced large amounts of esters. ValleRodríguez et al. (2012) showed that supplementation of the agave juice with certain specific amino acids allowed $H$. vinae to complete the fermentation. González-Robles et al. (2015) explored the use of mixed cultures of Saccharomyces/Hanseniaspora observing the contribution of the latter in aromatic profiles of Tequila. AmayaDelgado et al. (2013) carried out fermentations of $A$. tequilana juice at an industrial scale using two non-Saccharomyces yeasts ( $P$. kluyveri and $K$. marxianus) with a fermentation efficiency higher than $85 \%$ and an interesting production of volatile compounds, mainly esters. This behaviour was confirmed at laboratory scale by Segura-García et al. (2015).

Tequila fermentations are generally carried out in open tanks, allowing evaporation of alcohol and carbon dioxide to alleviate yeast stress. Nowadays, some distilleries use cooling systems to reduce alcohol evaporation and to keep fermentation temperature tolerable for yeasts (Gschaedler et al. 2015).

Finally, it is important to mention that during Tequila fermentation lactic acid bacteria from the genus Lactobacillus, Lactococcus, Leuconostoc and Pediococcus are also present and, Acetobacter, an acetic acid bacterium may appear in old fermented worts (Cedeño 2003). These bacteria may have a positive impact on the generation of volatile compounds, as has been reported in whiskey, cider, and wine fermentations. However, if the bacterial populations are too large, they could affect the ethanol yield and produce some undesirable compounds.

In the case of Mezcal, Bacanora and Raicilla fermentations, these are generally carried out with the agave fibers present (except for Mezcal from San Luis Potosi), increasing the fermentation time. A general characteristic of these processes is that 
they are completely spontaneous, without any control of the key parameters of fermentation, such as sugars concentration or temperature. In San Luis Potosi, the fermentation of A. salmiana subsp. crassispina juice is carried out without the agave fibers, with low initial sugar concentration and is generally induced by the addition of a mixed inoculum containing low counts $\left(>1 \times 10^{6}\right.$ cells $\left.\mathrm{mL}^{-1}\right)$ of non-Saccharomyces yeasts and bacteria. Verdugo Valdez et al. (2011) observed a short fermentation (around $30 \mathrm{~h}$ ), with low residual sugars concentration and yeast population between 10-15 x $10^{6}$ cells $\mathrm{mL}^{-1}$. The amount of ethanol and volatile compounds were relatively low and were directly related to the initial sugar content of the agave must. From Oaxaca, where spontaneous fermentation is generally carried out with agave fiber, Kirchmayr et al. (2017) published a study about Mezcal production process in two different distilleries, in two consecutive years. Fermentation kinetics and volatile compound generation differed markedly between the studied processes (all of them spontaneous), mainly due to the lack of control during the fermentation and changes in the ambient condition (mainly temperature). This study pointed out great differences in the initial sugar concentration and total yeast populations (that ranged from 12 to $180 \times 10^{6}$ cells $\left.\mathrm{mL}^{-1}\right)$. Low fermentation efficiencies were observed due to high concentration of residual sugars at the end of the fermentation. Nevertheless, this study also demonstrated that the employment of wild inocula in the fermentation of cooked agave juice may be a good practice in order to increase alcoholic fermentation efficiency.

There are very few in situ fermentation studies of agave distillates. However, in spontaneous fermentations, in which non-Saccharomyces, Saccharomyces, lactic and acetic acid bacteria participate, although they sometimes have low conversion rates of sugars to ethanol, they do result in beverages with complex sensory profiles that are 
currently sought by a new type of consumer. Some of the yeasts isolated from these spontaneous fermentations display interesting characteristics, compared with wine strains. Fiore et al. (2005) evaluated parameters of technological interest, such as $\mathrm{SO}_{2}$ and copper resistance, ethanol tolerance and enzymatic activities in Candida krusei, C. magnolia, Kloeckera africana, K.. apiculata, and S. cerevisiae strains isolated from agave, Sotol and grape must. All agave strains were more resistant to $\mathrm{SO}_{2}$ than wine strains, and non-Saccharomyces agave yeasts were more tolerant to ethanol. This behaviour is not common in non-Saccharomyces associated with alcoholic beverages. In contrast, all the non-Saccharomyces strains showed similarities in $\beta$-glucosidase and $\beta$-xylosidase activities, except $C$. krusei. Remarkable characteristics were the $\beta$ glucosidase activity of a $S$. cerevisiae strain and $\beta$-xylosidase activity of a $C$. krusei strain, both isolated during the fermentation of Sotol carried out with must and fiber. This special condition could have caused the adaptation of the yeasts that would explain these activities.

\section{Production of aromatic compounds}

Regarding the process of elaboration of these spirits, the production of volatile aromatic compounds in such beverages is influenced by several factors. These include raw materials, fructan hydrolysis processes (oven, acidic or enzymatic hydrolysis), spontaneous or directed fermentations, distilling systems (still or column) and finally aging (Table 16.5).

Table 16.5 here 
Raw materials used in agave distilled beverages play an important role in the development of the sensory characteristics of the final product. Compounds including terpenes, alcohols, esters, and acids derive from the raw materials (Prado-Jaramillo et al. 2015). Peña-Álvarez et al. (2004) identified diverse terpenes in different agave species used in Mezcal ( 7 in A. angustifolia, 9 in A. salmiana) and Tequila production (32 in A. tequilana). Arrizon et al. (2007) determined the volatile compounds in tequila and raicilla. Sixteen terpenes were found in both beverages mainly: $\beta$ myrcene, isocineole, linalool, 1-terpineol, 4-terpineol, citronellol, nerol, geraniol and nerolidol; 15 more were detected only in raicilla, predominantly $\alpha$-pinene, camphene, limonene, $\gamma$-terpinene, $\rho$-cymene, myrcenol, neryl acetate, geranyl acetate, $\alpha$ eudesmol. From these, geraniol, linalool, limonene, myrcenol, $\gamma$-terpinene, 4terpineol, were among others are found in the final product. This highlights the impact of the raw material on the sensory profiles of agave distillates (Tables 16.5).

During production of agave distillates, it is necessary to carry out the hydrolysis of fructans, which can be accomplished by a cooking process. During this process agaves heads and/or agave juice are exposed to temperatures between $95^{\circ} \mathrm{C}$ and $121^{\circ} \mathrm{C}$, causing caramelisation and Maillard reactions. Some compounds that have been identified in cooked agave juice are: 5-hydroxymethylfurfural, methyl-2furonoate and 2, 3-dihydroxy-3,5-dihydro-6-methyl-4 (H) -pyran-4-one (MancillaMargalli and López, 2002). Prado-Jaramillo et al.(2015) reported the presence of acids, aldehydes, ketones, esters, and mainly furans (1-furan-2-yl-ethanone, 5acetoxymethyl-furfural, 5-methyl-furfural, furfural and hydroxymethylfurfural) and terpenes ( $\alpha$-terpineol, $\Delta$-cadineno, linalool, nerolidol, ocimene and $\gamma$-terpinene). These are compounds that persist in the distilled and aged beverage (Tables 16.5). 
Another compound generated during cooking or the agave fructans hydrolysis stage is methanol, whose concentration is stipulated in the regulations of Tequila and Mezcal. Due to the cooking conditions (high temperatures and low $\mathrm{pH}$ ) methoxyl groups are released from the pectin present in the agave heads, and methanol is formed in the presence of water. This alcohol is partially separated during distillation (PradoRamírez et al. 2005).

The most studied stage in agave distillates production is fermentation. Usually, at the beginning of the process a high yeast diversity is present, mainly non-Saccharomyces species (of the genera Candida, Hanseniaspora, Meyerozyma, Kluyveromyces, Pichia, Torulaspora, Zygosaccharomyces, etc.) which produce a large amount of volatile compounds and flavour congeners that impact in the sensory quality of the agave spirits (Table 16.6). The generation of these compounds depends on different factors, including: agave species; preparation of the must with hydrolyzed agave juice, with or without bagasse fibers; spontaneous or induced fermentation; yeast strain; fermentation conditions (temperature, dissolved oxygen, $\mathrm{pH}$, nitrogen concentration), among others (Arrizon et al. 2002, 2006; Arellano et al. 2008; Díaz-Montaño et al. 2008; Verdugo-Valdez et al. 2011; López-Álvarez et al. 2012; Moran-Marroquín et al. 2011; Amaya-Delgado et al. 2013, Segura-García et al. 2015, González-Robles et al. 2015, Kirchmayr et al. 2017) (Tables 16.5, 16.6).

During agave juice fermentation higher alcohols are the most important aromatic compounds produced, representing between 50 to $90 \%$ of the total of volatile compounds produced during this stage. These include, mainly: amyl alcohol, 1propanol, isobutanol and furfuryl alcohol (Gschaedler et al. 2015). Factors that influence their production are the yeast strain (Arellano et al. 2008; Díaz-Montaño et al. 2008; Segura et al. 2015), high fermentation temperature and low nitrogen 
concentration (Arellano et al. 2008; Arrizon et al. 2006). Esters are the most diverse compounds found, and their production depends mainly on the yeast strain. NonSaccharomyces species as $K$. marxianus, $P$. kluyveri and $T$. delbrueckii have been reported to produce more esters than S. cerevisiae (Amaya-Delgado et al. 2013, Segura-García et al. 2015, Núñez-Guerrero et al. 2016). However, anaerobic conditions (Moran-Marroquín et al. 2011) as well as high nitrogen concentrations, can influence the production of these compounds in A tequilana and $A$ durangensis juices (Arrizon et al. 2002; Rutiaga-Quiñones et al. 2013). At the end of tequila fermentation, Prado-Jaramillo et al. (2015) detected 71 compounds belonging to alcohols, acids, terpenes, furans, aldehydes, ketones and esters (Table 16.5).

Other volatile compounds produced during agave must fermentation are: acetals, aldehydes, acids, ketones, phenols, hydrocarbons, sulfur etc., although they have been identified, have not been quantified, and the parameters that influence their production are still unknown (Prado-Jaramillo et al. 2015) (Table 16.5).

It is important to highlight that agave species, place of origin, age, year season, spontaneous fermentation, and fermentation conditions can change the profile of volatile compounds produced (Pinal et al. 2009). The different yeast and bacteria species that participate in the spontaneous fermentation of agave-spirits can also impact the production of non-volatile compounds such as: ethyl acetate, ethyl lactate, acetic acid and lactic acid, that modify the titratable acidity of the must (Kirchmayr et al. 2017; Escalante-Minakata et al. 2008; Narváez-Zapata et al. 2010; Páez-Lerma et al. 2013).

There are few reports regarding the production and recovery of volatile compounds during the distillation of agave spirits (Prado-Ramírez et al. 2005). In these beverages more than 200 compounds have reported mainly: alcohols, acids, terpenes, furans, 
aldehydes, ketones and esters, whose profile varies depending on the species of agave used, its region of origin, the fermentation process and distillation conditions (Table 16.5) (Álvarez-Ainza et al. 2013; Prado-Jaramillo et al. 2015).

Agave distillates can be aged in wooden (oak, white oak, holm oak) barrels for months or years, depending of the type of distillate to be obtain (Fig 16.4k). In aged agave spirits more 327 compounds have been identified (Prado-Jaramillo et al. 2015). During Tequila aging the main compounds detected are: higher alcohols, methanol, esters, furans, gallic acid, vanillin, syringaldehyde, synapinaldehyde, coniferaldehyde, syringic acid, ferulic acid, esculetin, scopoletin, cis/trans whisky lactones, guaiacol, 4ethyl guaiacol and, vainillin (González-Robles and Cook 2016).

\subsection{Recent developments and future prospects}

The great number of agave species and their many uses are a natural and cultural symbol of Mexico. For more than 10,000 years these plants have been used for different purposes (nutritional, medicinal, fibers extraction, production of alcoholic beverages, construction, etc.). This emphasises why the diversity of agaves must be protected to maintain their ecology, ethnobotany and evolution, ensuring their availability to support the economic and cultural needs of the Mexican people.

The production processes of Agave and Dasylirion spirits have to be understood and precisely described. The genetic diversity of the plants used as raw material as well as the production and composition of the must have to be determined. The microbiota present in the must that participates in the complex fermentation process has to be phenotypically and genotypically characterized, and their potential as starter cultures. Finally, the precise roles of microbes during spontaneous fermentations in the production of ethanol and aromatic compounds remains to be evaluated. 


\subsection{Yeasts in production of miscellaneous spirits}

This section covers yeast and fermentation aspects of selected miscellaneous distilled spirits. It is outwith the scope of this Chapter to provide a comprehensive coverage of these topics and the reader is directed to several publications and websites for more detailed information (eg. for fruit-based spirits: http://www.pediacognac.com/en/; for sugar/molasses-based spirits: Piggot (2003); and for whey-based spirits: O'Shea (2003).

\subsubsection{Yeasts in production of fruit-based spirits}

Various spirits are produced following the distillation of fermented fruit sugars. For example, brandies are distilled wines and eau-de-vies are distilled fruit beverages. The fruits in question are those from which fermentable sugars, principally glucose and fructose, can be easily extracted and include grapes, apples, plums, apricots and several others.

For brandies, including the best-known example Cognac, the starting material for the distillation is wine. Yeast and fermentation aspects of wine production have been well covered in previous Chapters in this book and the reader is also directly to the recent elegant paper on wine yeasts by Pretorius (2016).

Several naturally-occurring and selected yeasts are involved in grape fermentations for spirit production, principally including: S. cerevisiae, Candida famata and $K$. apiculata. For Cognac production, the Bureau National Interprofessionnel du Cognac (BNIC, http://www.bnic.fr/cognac/) in France recommends 8 strains of yeast (Dr L. Lurton, BNIC, personal communication) which will produce different concentrations of secondary fermentation metabolites that act as flavour congeners in Cognac spirits (eg. ethyl acetate, isoamyl acetate, higher alcohols, 2-phenyethanol, ethyl laurate etc.). 
Ester formation by Cognac yeasts is a desirable attribute as these compounds impart characteristic fruity and floral aromas to the spirit. The choice of yeast strain is therefore critical in defining spirit quality.

A typical composition of a freshly-distilled wine spirit like Cognac would comprise: $\sim 72 \% \mathrm{v} / \mathrm{v}$ ethanol; $\sim 28 \% \mathrm{v} / \mathrm{v}$ water and $<1 \%$ volatile substances. Of the latter, 80 olfactive zones have been characterized by gas chromatography-olfactometry and many of these have been identified (e.g. in the following chemical classes: alcohol, esters, aldehydes, norisoprenoïds, terpenes, etc.) in concentrations ranging from nanogram/1 to several hundred milligrams/l. Although Cognac aroma originates from the grapes, distillation and ageing, the role of yeast and progress of fermentation is of paramount importance for Cognac sensory characteristics. The BNIC have developed a Cognac aroma wheel that depicts the cycle of the seasons (Fig 16.5).

Fig 16.5 here

Cognac wine fermentations are complete within 4-8 days, depending on temperature which also influences volatile flavour and aroma compounds in the spirit. For example, increasing temperature (eg. 18 to $22^{\circ} \mathrm{C}$ ) results in elevated levels of higher alcohols, but decreasing levels of isoamyl acetate. In order to have some control over congener profiles and also off-flavours, the yeasts employed for Cognac fermentations (at an inoculation rate of around $1 \times 10^{6}$ cells $/ \mathrm{mL}$ ) must be able to initiate alcoholic fermentation of grape must rapidly to prevent growth of contaminant microbes. This is especially important since $\mathrm{SO}_{2}$ is not allowed in Cognac production processes. In addition, the level of utilisable nitrogen in the grape must will dictate the kinetics and extent of yeast growth and nitrogen deficiency can be addressed by supplementation (within defined limits) with ammonium salts. Rapid yeast growth 
also exerts some degree of control over bacterial malolactic fermentation. Generally speaking, distillers producing wine-based spirits such as Cognac must select the most suitable strains of $S$. cerevisiae to dominate the fermentation and to liberate the correct balance of congeners into the spirit. In other words, the sensory profile of a wine spirit, as it is with other alcoholic beverages, is highly yeast strain-dependent.

\subsubsection{Yeasts in production of sugarcane-based spirits}

Various distilled spirits can be produced from sugar cane. Those emanating from the fermentation of the raw sugar cane juice are spirits such as Rhum Agricole (from Réunion and Martinique) and Cachaça (from Brazil), and those emanating from sugar cane molasses are spirits collectively called rum. There are several styles of rum, classed as white rum (having no colour, generally unaged in oak wood barrels); amber rum (with a golden colour, typically aged in oak barrels for between 1-3 years) and dark rum (typically aged 3 or more years). Molasses (or sugar cane juice) fermentations can either be spontaneous, relying on natural microorganisms (wild yeasts and bacteria) indigenous to the raw materials and distillery environments, or can be specially selected $S$. cerevisiae strains to be used as starter cultures. Fermentations can either be batch, continuous or semi-continuous processes, but in all cases, the main fermentable sugar available to yeast is sucrose. Therefore, yeasts with a high invertase activity are employed to facilitate sucrose hydrolysis to glucose and fructose. In addition to $S$. cerevisiae, other yeasts play important roles in rum fermentations such as Schizosaccharomyces pombe (Pech et al. 1994; Fahrasmane et al. 1988). This fission yeast can impart desirable flavour and aroma characteristics, particularly in dark, heavy rum styles. Compared with S. cerevisiae, Schizo. pombe conducts slower fermentations, produces less higher alcohols and fatty acids, but 
more esters. This yeast is favoured by low $\mathrm{pH}$ and higher sugar concentrations in molasses. Schizo. pombe also has interesting enological properties such as maloethanolic fermentation (Benito et al. 2012).

\subsubsection{Yeasts in production of whey-based spirits}

There are a variety of beverages, both alcoholic and non-alcoholic, derived from cheese whey, a by-product of the cheese-making process (Jeličić et al. 2008). In addition to whey "beer" and whey "wine", distilled spirits are also made from cheese whey (O'Shea 2003). In all cases, the fermentation of lactose in the whey is conducted by lactose-fermenting yeasts, notably K. marxianus (Walker and O'Neill 1990). The spirits include whey-based vodka and such beverages are produced on a large scale in several countries (e.g. Ireland, New Zealand, Turkey). Because whey only contains around $5 \% \mathrm{w} / \mathrm{v}$ lactose, it has to be concentrated (following ultrafiltration to remove whey protein) using reverse osmosis to increase the final alcohol concentration in the beer prior to distillation. The alcohol levels produced in whey fermentations are also restricted by the relatively low ethanol tolerance of Kluyveromyces spp. employed and this is an area for further yeast research.

\subsection{Conclusions and future prospects}

The diversity of distilled spirits is linked to the diverse starting raw materials and the main available sugars for yeast fermentation, which are: maltose (for whiskies), glucose and fructose (for brandies), sucrose (for rums), lactose (for cheese wheybased spirits) and fructose (for Tequila and M.ezcal). The choice of yeast strain for

such spirits must therefore reflect specific sugar fermentability For example, a fructophilic yeast would not be appropriate for malt wort fermentations for whisky. 
Many developments have taken place aimed at improving the efficiency of sugar conversion to alcohol, and in selecting new strains of $S$. cerevisiae to impart desirable sensory characteristics to spirit beverages. Walker et al. (2012) have identified desirable characteristics for Scotch whisky distilling yeast strains.

Although scientific advances in knowledge of yeast genetics and molecular biology as applied to brewing and winemaking have been made in recent times this has proved of very limited practical value to the distiller. In particular, strain engineering employing recombinant DNA techniques has not found favour for production of spirit beverages, mainly due to public perception issues. In other words, the constraints in employing GM yeast strains in this field are primarily sociological, rather than technological. Self-cloned yeast strains, involving yeast-yeast genetic modification may be more attractive to consumers than yeast transformation with non-yeast genes and may also be more favourable from a regulatory standpoint (Argyros and Stonehouse 2017). Where such genetically manipulated (GM) strains are being successfully exploited is in the fuel ethanol sector (see Walker and Walker, 2018). Nevertheless, some molecular biological techniques applied to beverage spirit yeast strains have proved useful. For example, proteomic analysis of whisky yeast strains during fermentation has provided insight into stress responses of yeast during fermentation of industrial grain mashes (Hansen et al. 2006). Molecular genetics and bioinformatics applied to industrial strains of S. cerevisiae represent powerful tools in monitoring and control of fermentations for beer, wine and spirit production (Bond and Blomberg 2006). Future research into yeast physiology and genetics will lead to a deeper understanding of $S$. cerevisiae strains exploited for spirit fermentations. In turn, novel yeast strains with interesting new attributes with improved fermentation performance and flavour quality are on the horizon. 


\subsection{References}

Aguirre D, Eguiarte L (2013) Genetic diversity, conservation and sustainable use of wild Agave cupreata and Agave potatorum extracted for mezcal production in Mexico. J Arid Environ 90:36-44

Álvarez-Ainza ML, González-Ríos H, González-León A, Ojeda-Contreras AJ, Valenzuela-Quintanar AI, Acedo-Félix E 2013. Quantification of mayor volatile compounds from artisanal agave distilled: Bacanora. Am J Anal Chem 4: 683-688

Álvarez-Ainza ML, Zamora-Quiñonez KA, Moreno-Ibarra GM, Acedo-Félix E (2015) Genomic diversity of Saccharomyces cerevisiae yeasts associated with alcoholic fermentation of Bacanora produced by artisanal methods. Appl Biochem Biotech 175(5):2668-2676

Amaya-Delgado L, Herrera-López EJ, Arrizon J, Arellano-Plaza M, Gschaedler A (2013) Performance evaluation of Pichia kluyveri, Kluyveromyces marxianus and Saccharomyces cerevisiae in industrial tequila fermentation. World J Microb Biot 29(5):875-881

Andrade Meneses OE, Ruiz Terán F (2004) Study of yeast populations in a mezcal fermentation. In Abstracts of the $11^{\text {th }}$ International Congress on Yeasts. Yeasts in Science and Technology, The Quest for Sustainable Development., Rio de Janeiro, 15-20 August 2004

Arellano M, Pelayo C, Ramírez J, Rodríguez I (2008) Characterization of kinetic parameters and the formation of volatile compounds during the tequila fermentation by wild yeasts isolated from agave juice. J Ind Microbiol Biotechnol 35(8):835-841

Argyros, DA and Stonehouse, EA (2017) Yeast strain development for alcohol production. In: The Alcohol Textbook $6^{\text {th }}$ Edition. pp 287-297. Eds. Walker, GM, Abbas, C, Ingledew,WM and Pilgrim, C (2017). (ISBN 978-0-692-93088-5). Ethanol Technology Institute, Duluth, USA

Arratia Mireles JM (2009) Diversidad genética de levadura de mezcal tamaulipeco. M Sc Dissertation, Centro de Biotecnología Genómica, Instituto Politécnico Nacional. Tamaulipas

Arrizon J, Gschaedler A (2002) Increasing fermentation efficiency at high sugars concentrations by supplementing an additional source of nitrogen during the exponential phase of the tequila fermentation process. Can J Microbiol 48:965-970

Arrizon, J, Fiore C, Acosta G, Romano P, Gschaedler A (2006) Fermentation behaviour and volatile compound production by agave and grape must yeasts in high sugar Agave tequilana and grape must fermentations. Antonie Van Leeuwenhoek 89(1):181-189 
Arrizon J, Arizaga JJ, Hernández RE, Estarrón M, Gschaedler A (2007) Production of volatile compounds in tequila and raicilla musts by different yeasts isolated from Mexican agave beverages. In: Tunick MH, González de Mejía E (eds) Hispanic Foods Chemistry and Flavor. American Chemical Society Symposium Series 946, Washington, pp167-177

Benito, S, Palomero, F, Morata, A, Claderon, F and Suarez-Lepe (2012) New applications for Schizosaccharomyces pombe in the alcoholic fermentation of red wine. International Journal of Food Science \& Technology doi:10.1111/j.13652621.2012.03076

Bond, U and Blomberg, A (2006) Principles and applications of genomics and proteomics in the analysis of industrial yeast strains. In: The Yeast Handbook. Yeasts in Food and Beverages. Eds A Querol and GH Fleet. pp 175-213. Springer-Verlag, Berlin \& Heidelberg.

Bryce, J. H. and Stewart, G. G. (2004) Distilled Spirits: Tradition and Innovation. Nottingham: Nottingham University Press.

Ceballos-Magaña SG, de Pablos F, Jurado JM, Martín MJ, Alcázar Á, MuñizValencia R, Gonzalo-Lumbreras R, Izquierdo-Hornillos R (2013) Characterisation of tequila according to their major volatile composition using multilayer perceptron neural networks. Food Chem 136 (3-4):1309-1315

Cedeño M (2003) Tequila production from agave: historical influences and contemporary processes. In: Jacques KA, Lyons TP, Kelsall DR (eds) The Alcohol Textbook, $4^{\text {th }}$ edn. Nottingham University Press, Nottingham, p 223-245

De la Garza-Toledo H, Martínez M, Lara L, Rodríguez-Herrera R, RodríguezMartínez J, Aguilar CN (2008) Production of a Mexican Alcoholic Beverage: Sotol. Res J Biolog Sci 3(6):566-571

De la Garza H, Buenrostro J, Reyes-Vega M, Rodríguez R, Martínes DG, Aguilar CN (2010) Chemical profile of sotol analyzed by solid phase microextraction-gas chromatography. Ame J Agr Biol Sci 5(3):261-268

De León-Rodríguez A, González-Hernández L, Barba de la Rosa A, EscalanteMinakata P, López MG (2006) Characterization of volatile compounds of mezcal, an ethnic alcoholic beverage obtained from Agave salmiana. J Agric Food Chem 54:1337-1341

De León-Rodríguez A, Escalante-Minakata P, Barba de la Rosa AP, Blaschek HP (2008) Optimization of fermentation conditions for the production of the mezcal from Agave salmiana using response surface methodology. Chem Eng Process. Process Intensif 47(1): 76-82

De los Ríos-Deras GC, Rutiaga-Quiñones OM, López-Miranda J, Páez-Lerma JB, López M, Soto-Cruz NO (2015) Improving Agave duranguensis must for enhanced fermentation. c/n ratio effects on mezcal composition and sensory properties. Rev Mex Ing Chím 14(2):363-371 
Díaz-Montaño DM, Délia ML, Estarrón-Espinosa M, Strehaiano P (2008) Fermentative capability and aroma compound production by yeast strains isolated from Agave tequilana Weber juice. Enzyme Microb Tech 42(7):608-616

Escalante-Minakata P, Blaschek HP, Barba De la Rosa AP, Santos L, De LeónRodríguez A(2008) Identification of yeasts and bacteria involved in the mezcal fermentation of Agave salmiana. Lett Appl Microbiol 46(6):626-630

Fahrasmane, L., Ganou-Parfait, B. \& Parfait, A. (1988). Yeast flora of Haitian rum distilleries. MIRCEN Journal of Applied Microbiology and Biotechnology, 4: 239241

Fiore C, Arrizon J, Gschaedler A, Flores J, Romano P (2005) Comparison between yeasts from grape and agave musts for traits of technological interest. World $\mathrm{J}$ Microbiol Biotechnol 21:1141-1147

Garcia-Soto MJ, Jimenez-Islas H, Navarrete-Bolaños JL, Rico-Martínez R, MirandaLópez R, Botello-Álvarez JE (2011) Kinetic study of the thermal hydrolysis of Agave salmiana for mezcal production. J Agric Food Chem 59(13):7333-7340

González-Robles IW, Estarrón-Espinosa M, Díaz-Montaño DM (2015) Fermentative capabilities and volatile compounds produced by Kloeckera/Hanseniaspora and Saccharomyces yeast strains in pure and mixed cultures during Agave tequilana juice fermentation. Antonie van Leeuwenhoek 108(3):525-536

González-Robles IW, Cook DJ (2016) The impact of maturation on concentrations key odour active compounds which determine the aroma of tequila. J Inat Brew 122 (3):369-380

Goodall, I, Fotheringham, R, Murray, D, Speers, RA, Walker, GM (2015) Distilled Spirits: Future Challenges, New Solutions; Context Products Ltd.: Packington, UK

Gschaedler Mathis A, Ramírez Cordova J, Diaz Montaño D, Herrera-López JE, Arellano-Plaza M, Arrizon-Gaviño J, Pinal-Zuazo L (2004) Fermentación: etapa clave en la elaboración del tequila. In: Gschaedler Mathis AC, Ruiz González JA (eds). Ciencia y Tecnología del Tequila: Avances y perspectivas. Centro de Investigación y Asistencia en Tecnológica y Diseño del Estado de Jalisco AC (CIATEJ), Guadalajara, México, p 62-12

Gschaedler Mathis A, Amaya-Delgado L, Arellano-Plaza M, Arrizón-Gabiño J, Herrera-López E, Iñiguez-Muñoz L, Kirchmayr M (2015) La fermentación: etapa clave en la elaboración del tequila. In: Gschaedler Mathis AC, Rodríguez-Garay B, Prado-Ramírez R, Flores-Montaño JL. (eds.). Ciencia y Tecnología del Tequila, avances y perspectivas. Centro de Investigación y Asistencia en Tecnología y Diseño del Estado de Jalisco AC (CIATEJ), Guadalajara, México, p 97-170

Hansen, R, Pearson, SY, Brosnan, JM, Meaden, PG and Jamieson, DJ (2006) Proteomic analysis of a distilling strain of Saccharomyces cerevisiae during industrial grain fermentation. Applied Microbiology and Biotechnology 72: 116-125 
Jeličić, I, Božani, R and Tratnik, L (2008) Whey-based beverages- a new generation of diary products. Mljekarstvo 58: 257-274

Jones, RC (1998) Distillery yeast technology. In: Proceedings of the $5^{\text {th }}$ Aviemore Conference on Malting, Brewing \& Distilling. Eds I Campbell and FG Priest. pp 6577. Institute of Brewing, London

Kirchmayr MR, Arellano Plaza M, Estarrón-Espinosa M, Gallardo Valdez J, Gschaedler Mathis AC, López Ramírez JE, Navarro Hurtado A, Prado Ramírez R, Ramírez Romo (2014) Manual para la estandarización de los procesos de producción de mezcal guerrerense. Centro de Investigación y Asistencia en Tecnología y Diseño del Estado de Jalisco, Guadalajara, Jalisco. México

Kirchmayr M, Segura LE, Lappe-Oliveras P, Moreno-Terrazas R, de la Rosa M, Gschaedler Mathis A (2017) Impact of environmental conditions and process modifications on microbial diversity, fermentation efficiency and chemical profile during the fermentation of Mezcal in Oaxaca. LWT Food Sci Technol 79:160-169

Korhola, M, Harju, L and Lehtonen, M (1989) Fermentation. In: The Science and Technology of Whiskies. Eds. JR Piggott, R Sharp and REB Duncan. pp 89-117. Longman Scientific and Technical, Harlow

Lachance MA (1995) Yeast communities in a natural tequila fermentation. Antonie Van Leeuwenhoek 68:151-160

Lachenmeier DW, Sohnius, EM, Attig R et al (2006) Quantification of selected volatile constituents and anions in Mexican Agave spirits (Tequila, Mezcal, Sotol, Bacanora). J Agric Food Chem 54(11):3911-3915

Lappe P, Ulloa M., Arce Rocha G, Cáceres Farfán M, Tapia-Tussell R, Pérez-Brito D, Larque A (2004) Isolation and identification of the mycobiota present in Agave fourcroydes. In Abstracts of the $11^{\text {th }}$ International Congress on Yeasts. Yeasts in Science and Technology, The Quest for Sustainable Development., Rio de Janeiro, 15-20 Aug 2004

Lappe-Oliveras P, Moreno-Terrazas R, Arrizon-Gaviño J, Herrera-Suárez T, GarcíaMendoza A, Gschaedler-Mathis A (2008). Yeasts associated with the production of Mexican alcoholic non distilled and distilled Agave beverages. FEMS Yeast Res 8:1037-1052

López-Ramírez JE, Martín-del-Campo ST, Escalona-Buendía H, García-Fajardo JA, Estarrón-Espinosa M (2013) Physicochemical quality of tequila during barrel maturation. A preliminary study. CyTA J Food, 11(3):223-233

Lea, AGH and Piggott, JRP (2003) Fermented Beverage Production. $2^{\text {nd }}$ Ed. Springer (ISBN 0306472759)

López-Álvarez A., Díaz-Pérez AL, Sosa-Aguirre C (2012) Ethanol yield and volatile compound content in fermentation of agave must by Kluyveromyces marxianus 
UMPe-1 comparing with Saccharomyces cerevisiae baker's yeast used in tequila production. J Biosci Bioeng 113(5):614-618

López-Ramírez JE, Martín-del-Campo ST, Escalona-Buendía H, García-Fajardo JA, Estarrón-Espinosa M (2013) Physicochemical quality of tequila during barrel maturation. A preliminary study. CyTA J Food, 11(3):223-233

Mancilla-Margalli N, López M (2002) Generation of Maillard compounds from inulin during the thermal processing of Agave tequilana Weber var. azul, J Agric Food Chem 50:806-812

Mancilla-Margalli N, Lopez M (2006) Water-soluble carbohydrates and fructan structure patterns from Agave and Dasylirion species. J Agric Food Chem 54:78327839

Martínez-Aguilar JF, Peña-Álvarez A (2009). Characterization of five typical agave plants used to produce mezcal through their simple lipid composition analysis by gas chromatography. J Agric Food Chem 57(5):1933-1939

McGill, DJ (1990) Brewers yeast effect. In: Proceedings of the 3rd Aviemore

Conference on Malting, Brewing \& Distilling. Ed I Campbell. pp 407-412. Institute of Brewing, London

Molina-Guerrero JA, Botello-Álvarez JE, Estrada-Baltazar A, Navarrete-Bolaños JL, Jiménez-Islas H, Cárdenas-Manríquez M, Rico-Martínez R (2007) Compuestos volátiles en el mezcal. Rev Mex Ing Chim 6(1):41-50

Morán-Marroquín GA, Cordova J, Valle-Rodríguez JO, Estarrón-Espinosa M, DíazMontaño D.M. (2011) Effect of dilution rate and nutrients addition on the fermentative capability and synthesis of aromatic compounds of two indigenous strains of Saccharomyces cerevisiae in continuous cultures fed with Agave tequilana juice. Int J Food Microbiol 151(1):87-92

Muñoz-Muñoz AC, Pichardo-Molina JL, Ramos-Ortíz G, Barbosa-García JL, Maldonado MA, Meneses NE, Ornelas A, Escobedo P, López de Alba L (2010) Identification and quantification of furanic compounds in tequila and mezcal using spectroscopy and chemometric methods. J Brazil Chem Soc 21(6):1077-1087

Murray, DM (2017) Distillation practices for beverage alcohol and impact on flavour. In: The Alcohol Textbook $6^{\text {th }}$ Edition. pp 455-469. Eds. Walker, GM, Abbas, C, Ingledew, WM and Pilgrim, C (2017). (ISBN 978-0-692-93088-5). Ethanol Technology Institute, Duluth, USA

Narváez-Zapata JA, Rojas-Herrera RA, Rodríguez-Luna IC, Larralde-Corona CP (2010) Culture-independent analysis of lactic acid bacteria diversity associated with mezcal fermentation. Curr Microbiol 61(5):444-450

Núñez-Guerrero ME, Páez-Lerma JB, Rutiaga-Quiñones OM, González-Herrera SM, Soto-Cruz NO (2016) Performance of mixtures of Saccharomyces and non- 
Saccharomyces native yeasts during alcoholic fermentation of Agave duranguensis juice. Food Microbiol 54:91-97

O'Shea, J (2003) Whey alcohol - a viable outlet for whey? The Alcohol Textbook $4^{\text {th }}$ Edition. Edited by KA Jacques, TP Lyons and DR Kelsall. Nottingham University Press. ISBN 1-897676-13-1. pp 65-73

Passoth, V, Blomqvist, J and Schnurer, J (2007) Dekkera bruxellensis and Lactobacillus vini form a stable ethanol-producing consortium in a commercial alcohol production process. Applied and Environmental Microbiology 73: 4354-4356

Páez-Lerma JB, Arias-García A, Rutiaga-Quiñones OM, Barrio E, Soto-Cruz N (2013) Yeasts isolated from the alcoholic fermentation of Agave duranguensis during mezcal production. Food Biotechnol 27(4):342-356

Pech, B, Lavoue, G, Parfait, A. \& Belin, JM (1984). Rum fermentation: suitability of strains of Schizosaccharomyces pombe. Science des Aliments, 4: 67-72

Peña-Álvarez A, Díaz L, Medina A, Labastida C, Capella S, Vera LE (2004) Characterization of three Agave species by gas chromatography and solid-phase microextraction-gas chromatography-mass spectrometry. J Chromatogr A 1027:131136

Peña-Álvarez A, Capella S, Juárez R, Labastida C (2006). Determination of terpenes in tequila by solid phase microextraction-gas chromatography-mass spectrometry. $\mathrm{J}$ Chromatogr A 1134(1-2): 291-297

Piggot, R (2003) Production of heavy and light rums: fermentation and maturation. The Alcohol Textbook $4^{\text {th }}$ Edition. Edited by KA Jacques, TP Lyons and DR Kelsall. Nottingham University Press. ISBN 1-897676-13-1 pp246-253

Pinal L, Cornejo E, Arellano M, Herrera E, Nuñez L, Arrizon J, Gschaedler A (2009). Effect of Agave tequilana age, cultivation field location and yeast strain on tequila fermentation process. J Ind Microbiol Biotechnol 36(5): 655-661

Prado-Jaramillo N, Estarrón-Espinosa M, Escalona-Buendía H, Cosío-Ramírez R, Martín-del-Campo ST (2015) Volatile compounds generation during different stages of the Tequila production process. A preliminary study. LWT Food Sci Technol 61(2):471-483

Prado-Ramírez R, Gonzáles-Alvarez V, Pelayo-Ortiz C, Casillas N, EstarrónEspinosa M, Gómez-Hernández HE (2005) The role of distillation on the quality of tequila. Int J Food Sci Technol 40:701-708

Pretorius, IS (2016) Conducting Wine Symphonics with the Aid of Yeast Genomics Beverages 2(4), 36; doi:https://doi.org/10.3390/beverages2040036

Reyes-Valdés MH, Benavides-Mendoza A, Ramírez-Rodríguez H (2012) Biología e importancia del sotol (Dasylirion spp). Parte I: Sistemática, genética y reproducción. Planta 7 (14):11-14 
Rutiaga-Quiñones OM, Córdova É, Martell-Nevárez MA, Guillamón JM, Rozès N, Páez J (2012) Volatile compound production in Agave duranguensis juice fermentation using four native yeasts and $\mathrm{NH} 4 \mathrm{Cl}$ supplementation. Eur Food Res Technol 235(1): 29-35

Russell, I and Stewart, GG (2014) Whisky: Technology, Production and Marketing, 2nd ed.; Academic Press/Elsevier: Boston, MA, USA.(ISBN 978-0-12-401735-1)

Segura-García LE, Taillandier P, Brandam C, Gschaedler A (2015) Fermentative capacity of Saccharomyces and non-Saccharomyces in agave juice and semisynthetic medium. LWT-Food Sci Technol 60(1):284-291

Smith, KB (2017) Yeast practices in the production of American whiskies. In: The Alcohol Textbook $6^{\text {th }}$ Edition. pp 335-361. Eds. Walker, GM, Abbas, C, Ingledew,WM and Pilgrim, C (2017). (ISBN 978-0-692-93088-5). Ethanol Technology Institute, Duluth, USA

Soto-García E, Rutiaga-Quiñones M, López-Miranda J, Montoya-Ayón L, Soto-Cruz O. 2009. Effect of fermentation temperature and must processing on process productivity and product quality in mescal fermentation. Food Control 20: 307-309

Thomas, KC, Hynes, SH and Ingeldew, WM (2001) Effect of lactobacilli on yeast growth, viability and batch and semi-continuous alcoholic fermentation of corn mash. Journal of Applied Microbiology 90: 819-828

Torres I, Blancas J, León A Casas A (2015) TEK, local perceptions of risk, and diversity of management practices of Agave inaequidens in Michoacán, México 11 (61):1-20

Valle-Rodríguez JO, Hernández-Cortés G, Cordova-López J, Estarrón-Espinosa M, Díaz-Montaño DM (2012) Fermentation of Agave tequilana juice by Kloeckera africana: influence of amino-acid supplementations Antonie Van Leeuwenhoek 101:195-204

Vallejo-Córdoba A, Gonzalez-Córdoba M, Estrada-Montoya (2005) The latest advantages in the characterization of Mexican distilled agave beverage: Tequila, Mezcal and Bacanora. In Abstracts of the $229^{\text {th }}$ National Meeting of the American Chemical Society, San Diego, 13-17 March 2005

van Beek, S, and Priest, FG (2002) Evolution of the lactic acid bacterial community during malt whisky fermentation: a polyphasic study. Applied and Environmental Microbiology 68: 297-305

Vera-Guzmán AM, Santiago-García PA, López MG (2009) Compuestos volátiles aromáticos generados durante la elaboración de mezcal de Agave angustifolia y Agave potatorum. Rev Fitotec Mex 32(4):273-279 
Vera-Guzmán AM, López MG, Chávez-Servia JL (2012) Chemical composition and volatile compounds in the artisanal fermentation of mezcal in Oaxaca, Mexico. Afric $\mathbf{J}$ Biotech 11(78):14344-14353

Vera-Guzmán AM, Guzmán-Gerónimo RI, López MG, Chávez-Servia JL (2018) Volatile Compound Profiles in Mezcal Spirits as Influenced by Agave Species and Production Processes. Beverages 4: 1-10

Verdugo Valdez A., Segura García L, Kirchmayr M, Ramírez Rodríguez P, González Esquinca A, Coria R, Gschaedler Mathis A (2011) Yeast communities associated with artisanal mezcal fermentations from Agave salmiana. Antonie van Leeuwenhoek 100(4):497-506

Waleckx E, Gschaedler A, Colonna-Ceccaldi B, Monsan P (2008) Hydrolysis of fructans from Agave tequilana Weber var. azul during the cooking step in a traditional tequila elaboration process. Food Chem 108: 40-48

Walker, GM (1998) Yeast Physiology and Biotechnology. J. Wiley \& Sons, Chichester and New York

Walker, GM (2011) Fuel alcohol: current production and future challenges. Journal of the Institute of Brewing 117: 3-22

Walker, GM and O'Neill, JD (1990) Morphological and metabolic changes in Kluyveromyces marxianus var marxianus NNRLy 2415 during fermentation of lactose. Journal of Chemical Technology \& Biotechnology 49: 75-89

Walker, GM and van Dijck, P (2006) Physiological and molecular responses of yeasts to the environment. In: The Yeast Handbook. Yeasts in Food and Beverages. Eds A Querol and GH Fleet. pp 111-152. Springer-Verlag, Berlin \& Heidelberg

Walker, GM and Hughes, PS (2010) Distilled Spirits. New Horizons: Energy, Environment and Enlightenment; Nottingham University Press: Nottingham, UK

Walker, G. and Hill, A. (2016). Saccharomuyces cerevisiae in the production of whisky. In: Beverages. Special Edition on Saccharomyces cerevisiae. Eds: Walker, G.M, and Stewart, G.G. MDPI AG Publishers, Basel, Switzerland. Beverages 2(4), 38; doi:10.3390/beverages2040038

Walker, GM and Stewart, GG (2016) Saccharomuyces cerevisiae in the production of fermented beverages. In: Beverages. Special Edition on Saccharomyces cerevisiae. Eds: Walker, G.M, and Stewart, G.G. MDPI AG Publishers, Basel, Switzerland. Beverages 2(4), 38; doi:10.3390/beverages2040038

Walker, GM and Walker, RSK (2018) Enhancing yeast alcoholic fermentations. Advances in Applied Microbiology, Volume 105 ISSN 0065-2164

https://doi.org/10.1016/bs.aambs.2018.05.003

Walker, GM, Bringhurst, T, Brosnan, J, Jack, F (2012) Selecting new distilling yeasts for improved fermentation and for sustainability. In Distilled Spirits: Science and 
Sustainability. pp 127-136 Eds. Walker, G.M., Goodall, I., Fotheringham, R., Murray, D., Eds.; Nottingham University Press: Nottingham, UK

Walker, GM, Abbas, C, Ingledew,WM and Pilgrim, C (2017) Eds. The Alcohol Textbook $6^{\text {th }}$ Edition (ISBN 978-0-692-93088-5). Ethanol Technology Institute, Duluth, USA.592pp

Watanabe, S, Kanauchi, M, Kakuta, T, Koizumi, T (2007) Isolation and characteristics of lactic acid bacteria in Japanese spirit Awamori mash. Journal of the Institute of Brewing 65: 197-201

Watson, DC (1993) Yeasts in distilled alcoholic beverage production. In: The Yeasts. $2^{\text {nd }}$ Edition. Vol 5: Yeast Technology (eds AH Rose \& JS Harrison), pp 215-244. Academic Press, London

Zamora-Quiñonez K (2006) Caracterización fenotípica de levaduras presentes durante el proceso de fermentación del Bacanora. BSc Dissertation. Universidad de Sonora. Hermosillo, Sonora 


\section{Figure Captions}

Fig 16.1 The key role of Saccharomyces cerevisiae in production of fermented beverages. Adapted from Walker and Stewart (2016)

Fig 16. 2 Categories of the main global whiskies. Adapted from Walker and Hill (2016)

Fig 16.3 Summary of the main processes involved in Scotch malt whisky production. Adapted from Walker and Hill (2016)

Fig 16.4 Mezcal elaboration process.
(a) Agave angustifolia
(b) Raw agave heads or piñas
(c) Pit oven filed with stones
(d) Brick oven
(e) Cooked agave heads or piñas
(f) Rudimentary mill or tahona
(g) Fermentation of cooked agave must with fiber in wooden vats
(h) Fermentation of agave must without fiber in a brick tank
(i) Distillation of fermented agave must in a rudimentary still
(j) Arab type still
(k) Mezcal aging in oak barrels (optional)

Figure 16.5 Cognac aroma depicting the cycles of the seasons From: http://www.bnic.fr/cognac/ @ BNIC / Gérard MARTRON 
TABLES \& FIGURES

Table 16.1 Yeasts used in the production of selected distilled alcoholic beverages. Adapted from Walker \& Stewart (2016)

\begin{tabular}{|c|c|c|}
\hline Beverage & Yeast Involved & Comments \\
\hline Whisk(e)y & $\begin{array}{l}\text { Saccharomyces } \\
\text { cerevisiae }\end{array}$ & $\begin{array}{l}\text { Scotch whisky producers currently use selected distilling } \\
\text { strains of } S \text {. cerevisiae in three main formats, cream yeast, } \\
\text { pressed (cake) and dried yeast. Malt whisky distilleries } \\
\text { traditionally use pressed yeast, but larger grain distillers } \\
\text { have now adopted cream yeast. Dried yeasts are not as } \\
\text { prevalent as pressed and cream formats in whisky } \\
\text { fermentations. }\end{array}$ \\
\hline Rum & $\begin{array}{l}\text { Saccharomyces } \\
\text { cerevisiae and } \\
\text { Schizosaccharomyces } \\
\text { pombe }\end{array}$ & $\begin{array}{l}\text { Saccharomyces cerevisiae strains in rum fermentations are } \\
\text { developed as starter cultures and provide faster } \\
\text { fermentation with more higher alcohols and fatty acids, } \\
\text { but less esters resulting in lighter style rums. } \\
\text { Schizosaccharomyces pombe in rum fermentations } \\
\text { provides slower fermentations leading to less higher } \\
\text { alcohols and fatty acids, but more esters resulting in } \\
\text { heavy, strong aroma rums. Growth of Schiz. pombe is } \\
\text { favoured by low pH, higher sugar concentrations. }\end{array}$ \\
\hline $\begin{array}{l}\text { Tequila, } \\
\text { Mezcal, } \\
\text { Bacanora }\end{array}$ & $\begin{array}{l}\text { Natural yeasts in } \\
\text { artisanal Agave } \\
\text { fermentations }\end{array}$ & $\begin{array}{l}\text { Various yeasts have been isolated from such processes: } S . \\
\text { cerevisiae, Kluyveromyces marxianus, Pichia spp., } \\
\text { Brettanomyces spp., Rhodotorula } \text { spp., etc. }\end{array}$ \\
\hline $\begin{array}{l}\text { Brandies, } \\
\text { Gin, } \\
\text { Vodka, } \\
\text { etc. }\end{array}$ & $\begin{array}{l}\text { Saccharomyces } \\
\text { cerevisiae }\end{array}$ & $\begin{array}{l}\text { For brandies, cognac, etc. the base wine is produced by } \\
\text { pure starter cultures of } S \text {. cerevisiae. For gin, vodka, etc. } \\
\text { selected distilling strains of } S \text {. cerevisiae will be used. }\end{array}$ \\
\hline $\begin{array}{l}\text { Cheese } \\
\text { whey- } \\
\text { derived } \\
\text { beverages }\end{array}$ & $\begin{array}{l}\text { Kluyveromyces } \\
\text { marxianus }\end{array}$ & $\begin{array}{l}\text { Lactose-fermenting yeast to produce ethanol destined for } \\
\text { gin, vodka and cream liqueurs, etc. }\end{array}$ \\
\hline
\end{tabular}


Table16.2 Attributes of distiller's yeasts compared with wine yeasts

\begin{tabular}{|c|c|c|}
\hline Attribute & Distillers yeast & Wine yeasts \\
\hline Genetics & $\begin{array}{l}\text { Some whisky yeasts are natural hybrids } \\
\text { between } S \text {. cerevisiae and } S \text {. cerevisiae var. } \\
\text { diastaticus, but generally have complex } \\
\text { ploidy (e.g. polyploid). Some Scotch whisky } \\
\text { is made using mixtures of distiller's and } \\
\text { brewer's yeast cultures. S. cerevisiae strains } \\
\text { found in agave juice fermentations show high } \\
\text { genetic diversity. }\end{array}$ & $\begin{array}{l}\text { Wine yeasts are generally homothallic } \\
\text { diploids, but some strains may be } \\
\text { polyploid or aneuploid. }\end{array}$ \\
\hline Metabolism & $\begin{array}{l}\text { Rapid and complete fermentation of cereal } \\
\text { sugars. Most distillers yeasts will ferment } \\
\text { glucose, maltose, matotriose and some limited } \\
\text { fermentation of maltodextrins (glucoamylase } \\
\text { activity). Agave juice yeasts ferment fructose } \\
\text { and glucose. Production of desirable flavour } \\
\text { congeners (esters, organic acids, aldehydes, } \\
\text { higher alcohols etc.). In Scotch whisky and } \\
\text { Agave fermentations, there is also a } \\
\text { contribution to spirit flavour made by lactic } \\
\text { acid bacteria (see text). }\end{array}$ & $\begin{array}{l}\text { Vigorous fermentation desired, with } \\
\text { correct volatile acidity, aromatic } \\
\text { character (esters, succinic acid) and } \\
\text { viscosity (glycerol). Low } \\
\text { acetaldehyde and correct balance of } \\
\text { sulphur compound production. }\end{array}$ \\
\hline $\begin{array}{l}\text { Stress } \\
\text { physiology }\end{array}$ & $\begin{array}{l}\text { Stress-tolerance to temperature, ethanol, } \\
\text { osmotic pressure and competitive microbes } \\
\text { (lactic acid bacteria) desired. }\end{array}$ & $\begin{array}{l}\text { In addition to tolerance to variable } \\
\text { temperature, osmotic pressure and } \\
\mathrm{pH} \text {, wine yeasts should be } \mathrm{SO}_{2} \\
\text { tolerant. }\end{array}$ \\
\hline
\end{tabular}


Table 16.3 Important yeast-derived flavour congeners in distilled spirits

\begin{tabular}{ccc}
\hline Compound Class & Example & Flavour/Aroma \\
\hline \multirow{2}{*}{ Higher alcohols } & -propanol & Alcoholic \\
& Isobutanol & Pharmacy \\
Iso-amyl alcohol & (3-methylbutan-1-ol) & $\begin{array}{c}\text { Fusel, alcoholic, } \\
\text { fruity, banana }\end{array}$ \\
& Phenylethanol & Roses, perfume \\
& Ethyl acetate & Solvent, acetone \\
& Ethyl butyrate & Pineapple, banana, mango \\
& Ethyl caproate & Apple, aniseed \\
& Ethyl caprylate & Apple \\
Esters & Ethyl hexanoate & Pineapple, unripe banana \\
& Ethyl lactate & Butter/cream \\
& Ethyl octanoate & Sour apple, apricot \\
& Iso-amyl acetate & Banana, fruity \\
\hline S-Compounds & Hydrogen sulphide & Green apple \\
\hline Picinal diketones & Acetaldehyde & Butter, butterscotch \\
\hline Phenolics & 4-Vinyl guaiacol & Clove-like \\
\hline & & Rotten eggs \\
\hline
\end{tabular}


Table 16.4 Bacteria and yeasts isolated from the must fermentation process of Mexican distilled Agave and Dasylirion spirits

\begin{tabular}{|c|c|c|c|c|}
\hline Beverage & Agave species & $\begin{array}{l}\text { States of } \\
\text { production }\end{array}$ & Microbiota $^{1}$ & References \\
\hline Tequila & $\begin{array}{l}\text { A. tequilana } \\
\text { var. azul }\end{array}$ & $\begin{array}{l}\text { Jalisco, } \\
\text { regions of the } \\
\text { states of } \\
\text { Guanajuato, } \\
\text { Michoacán, } \\
\text { Nayarit and } \\
\text { Tamaulipas }\end{array}$ & $\begin{array}{l}\text { LAB, non-Saccharomyces (Candida spp., C. intermedia, } \\
\text { C. magnoliae, Dekkera anomala, D. bruxellensis, } \\
\text { Hanseniaspora spp., H. uvarum, H. vinae, Issatchenkia } \\
\text { orientalis, Kazachstania humilis, Kluyveromyces lactis, K. } \\
\text { marxianus, Meyerozyma guilliermondii, Pichia } \\
\text { membranifaciens, Torulaspora delbrueckii, } \\
\text { Zygosaccharomyces bailii) and Saccharomyces (S. } \\
\text { cerevisiae) yeasts } \\
\text { In industrialized process selected S. cerevisiae strains }\end{array}$ & $\begin{array}{l}\text { Lachance (1995) } \\
\text { Cedeño (2003) } \\
\text { Gschaedler et al. (2004) }\end{array}$ \\
\hline Mezcal & A. fourcroydes & Yucatán & $\begin{array}{l}\text { Non-Saccharomyces (C. parapsilosis, Clavispora } \\
\text { lusitaniae, Debaryomyces hansenii, I. orientalis, K. } \\
\text { Marxianus, Meyerozyma caribbica, M. guilliermondii, } \\
\text { Millerozyma farinosa, Ogataea angusta, } P . \\
\text { membranifaciens, T. delbrueckii, Wickerhamomyces } \\
\text { anomalus) } \\
\text { Basidiomycetous yeasts (Rhodotorula spp., Rhodotorula } \\
\text { mucilaginosa }\end{array}$ & Lappe et al. (2004) \\
\hline Mezcal & A. angustifolia & Oaxaca & $\begin{array}{l}\text { LAB, AAB; non-Saccharomyces (Candida spp., C. } \\
\text { apicola, C. boidinii, C. parapsilosis, C.zemplinina, } \\
\text { Citeromyces matritensis, Cl. lusitaniae, D. hansenii,.D. } \\
\text { anomala, Diutina rugosa, Hanseniaspora spp., H. } \\
\text { guilliermondii, H. osmophila, I. orientalis, K. lactis, }, \text {. } \\
\text { marxianus, M. guilliermondii, Pichia fermentans, } P . \\
\text { mandshurica, P. membranifaciens, Schizosaccharomyces }\end{array}$ & $\begin{array}{l}\text { Andrade Meneses and Ruiz } \\
\text { Terán (2004) } \\
\text { Kirchmayr et al. (2017) }\end{array}$ \\
\hline
\end{tabular}




\begin{tabular}{|c|c|c|c|c|}
\hline & & & $\begin{array}{l}\text { pombe, T. delbrueckii, W. anomalus, Z. bailii, Z. bisporus, } \\
\text { Z. rouxii) and Saccharomyces (S. cerevisiae) yeasts } \\
\text { Basidiomycetous yeasts (Cryptococcus uniguttulatus, } \\
\text { Naganishia albida, Pseudozyma prolifica, } \\
\text { Rhodosporidiobolus fluvialis, Rhodotorula glutinis, Rh. } \\
\text { mucilaginosa, Sporidiobolus salmonicolor }\end{array}$ & \\
\hline Mezcal & $\begin{array}{l}\text { A. salmiana } \\
\text { subsp. } \\
\text { crassispina }\end{array}$ & San Luis Potosí & $\begin{array}{l}\text { LAB, Zymomonas mobilis; non-Saccharomyces (C. } \\
\text { ethanolica, Cl. lusitaniae, I. orientalis, Kazachstania } \\
\text { exigua, K. marxianus. P. fermentans, Pichia. kluyverii, T. } \\
\text { delbrueckii, Z. bailii) and Saccharomyces }(\text { S. cerevisiae) } \\
\text { yeasts }\end{array}$ & $\begin{array}{l}\text { Escalante-Minakata et al. } \\
\text { (2008) } \\
\text { Verdugo Valdez et al. } \\
\text { (2011) }\end{array}$ \\
\hline Mezcal & $\begin{array}{l}\text { A. angustifolia } \\
\text { A. lechuguilla } \\
\text { A. montium- } \\
\text { sancticaroli }\end{array}$ & Tamaulipas & $\begin{array}{l}\text { LAB, Non-Saccharomyces (C. parapsilosis, Cl. lusitaniae, } \\
\text { K. marxianus, M. guilliermondii, P. kluyveri, } T \text {. } \\
\text { delbrueckii, Yamadazyma mexicana, Z. bailii) and } \\
\text { Saccharomyces (S. cerevisiae) yeasts } \\
\text { Basidiomycetous yeasts (Rh. mucilaginosa) }\end{array}$ & $\begin{array}{l}\text { Arratia (2009) } \\
\text { Narváez Zapata et al. (2010) }\end{array}$ \\
\hline Mezcal & A. durangensis & Durango & $\begin{array}{l}\text { Non-Saccharomyces (H. uvarum, } K . \text { marxianus, } T . \\
\text { delbrueckii, P.fermentans, Saturnispora diversa) and } \\
\text { Saccharomyces (S. cerevisiae) yeasts }\end{array}$ & Páez-Lerma et al. (2013) \\
\hline Mezcal & $\begin{array}{l}\text { A. cupreata } \\
\text { A. inaequidens }\end{array}$ & Michoacán & $\begin{array}{l}\text { Non-Saccharomyces (C. magnoliae, H. uvarum, I. } \\
\text { orientalis, ) and Saccharomyces (S. cerevisiae) yeasts }\end{array}$ & Kirchmayr et al. (2014) \\
\hline Bacanora & A. angustifolia & Sonora & $\begin{array}{l}\text { Non-Saccharomyces (Candida blankii, C. silvatica, D. } \\
\text { bruxellensis, Mi. farinosa, M. guilliermondii, Ogataea } \\
\text { polymorpha, T. delbrueckii) and Saccharomyces (S. } \\
\text { cerevisiae) yeasts. } \\
\text { Basidiomycetous yeasts (Rhodotorula } \text { sp.) }\end{array}$ & $\begin{array}{l}\text { Vallejo Córdoba et al. } \\
\text { (2005) } \\
\text { Zamora-Quiñonez (2006) } \\
\text { Álvarez Ainza et al (2015) }\end{array}$ \\
\hline Raicilla & $\begin{array}{l}\text { A. angustifolia } \\
\text { A. inaequidens } \\
\text { A. maximiliana }\end{array}$ & Jalisco & $\begin{array}{l}\text { Non-Saccharomyces (Cl. lusitaniae, K. marxianus) and } \\
\text { Saccharomyces (S. cerevisiae) yeasts }\end{array}$ & Arrizon et al. (2007) \\
\hline
\end{tabular}




\begin{tabular}{|l|l|l|l|l|}
\hline Sotol & Dasylirion spp. & Chihuahua & $\begin{array}{l}\text { Non-Saccharomyces (Dekkera sp., Kloeckera } \text { sp., } \\
\text { Hanseniaspora } \text { sp., Kluyveromyces spp., K. marxianus, } \\
\text { Zygosacharomyces sp., and Saccharomyces }(S . \\
\text { cerevisiae) yeasts }\end{array}$ & $\begin{array}{l}\text { De la Garza-Toledo } \text { et al. } \\
(2008)\end{array}$ \\
Durango \\
Coahuila
\end{tabular}

${ }^{1}$ Microbiota in spontaneous fermentation. $\mathrm{LAB}=$ Lactic acid bacteria, $\mathrm{AAB}=$ Acetic acid bacteria 
Table 16.5 Volatile compounds production along the elaboration process of agave distilled beverages

\begin{tabular}{|c|c|c|c|c|}
\hline Process stage & Beverage & Agave used & Volatile compounds & References \\
\hline \multirow[t]{3}{*}{ Raw material } & Tequila & A. tequilana var. azul & $\begin{array}{l}\text { Terpenes, alcohols, furans, } \\
\text { acids, aldehydes, esters, } \\
\text { hydrocarbures }\end{array}$ & Prado-Jaramillo et al. (2015) \\
\hline & $\begin{array}{l}\text { Mezcal, } \\
\text { Tequila }\end{array}$ & $\begin{array}{l}\text { A. angustifolia, } \text { A. salmiana } \\
\text { A. tequilana var. azul }\end{array}$ & Acids, esters, terpenes & Peña-Alvárez et al. (2006) \\
\hline & Mezcal & $\begin{array}{l}\text { A. salmiana subsp. crassispina, } \\
\text { A. salmiana var. salmiana, } \\
\text { A. angustifolia, A. cupreata, } \\
\text { A. karwinskii }\end{array}$ & Acids, lipids & Martínez-Aguilar et al (2009) \\
\hline \multirow[t]{3}{*}{$\begin{array}{l}\text { Cooking/ } \\
\text { hydrolysis }\end{array}$} & Tequila & A. tequilana var. azul & $\begin{array}{l}\text { Furans, pyrans, aldehydes, } \\
\text { nitrogen and sulfur compounds }\end{array}$ & $\begin{array}{l}\text { Mancilla-Margalli and López } \\
\text { (2002) }\end{array}$ \\
\hline & & & $\begin{array}{l}\text { terpenes, alcohols, furans, } \\
\text { acids, aldehydes, esters, } \\
\text { hydrocarbures }\end{array}$ & Prado-Jaramillo et al. (2015) \\
\hline & Mezcal & A. salmianas & Furans & García-Soto et al. (2011) \\
\hline \multirow[t]{12}{*}{ Fermentation } & Tequila & A. tequilana var. azul & Terpenes, alcohols, higher & Arrizon et al. (2006) \\
\hline & & & alcohols, furans, acids, esters, & Arellano et al. (2008) \\
\hline & & & aldehydes, hydrocarbures & Díaz-Montaño et al. (2008) \\
\hline & & & & Pinal et al. (2009) \\
\hline & & & & Moran-Marroquín et al. (2011) \\
\hline & & & & Valle-Rodríguez et al. (2012) \\
\hline & & & & Amaya-Delgado et al (2013) \\
\hline & & & & González-Robles et al. (2015) \\
\hline & & & & Prado-Jaramillo et al. (2015) \\
\hline & & & & Segura-García et al. (2015) \\
\hline & Mezcal & A. angustifolia & $\begin{array}{l}\text { Esters, higher alcohols, } \\
\text { aldehydes }\end{array}$ & Kirchmayr et al. (2017) \\
\hline & Mezcal & A. salmiana subsp. crassispina & $\begin{array}{l}\text { Esters, higher alcohols, } \\
\text { aldehydes }\end{array}$ & $\begin{array}{l}\text { Verdugo-Valdez et al. (2011) } \\
\text { De León-Rodríguez et al. (2008) }\end{array}$ \\
\hline
\end{tabular}




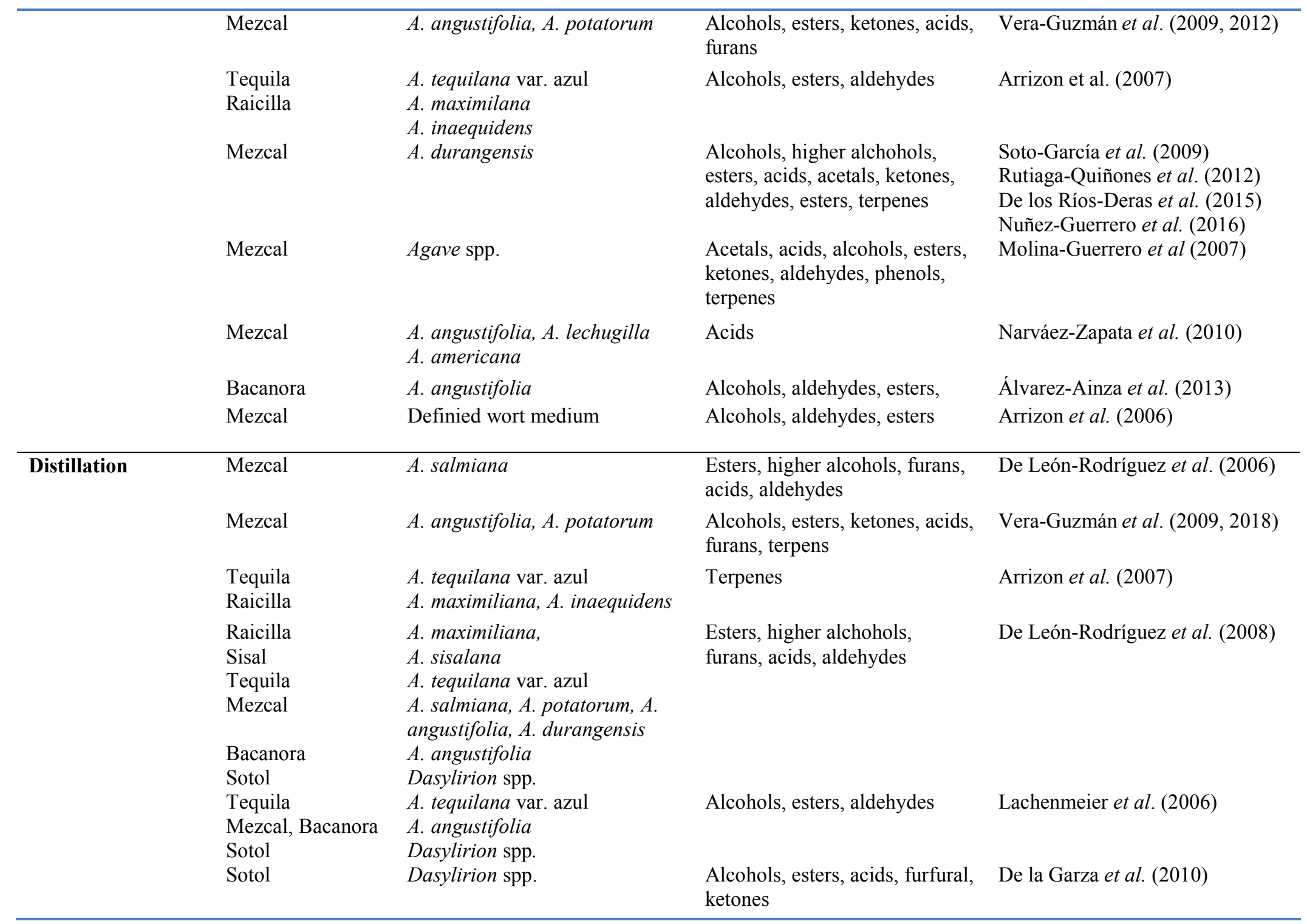




\begin{tabular}{|c|c|c|c|c|}
\hline & Mezcal & A. durangensis & $\begin{array}{l}\text { Esters, higher alchohols, acids } \\
\text { aldehydes, tepens, , ketones }\end{array}$ & De los Rios-Deras et al. (2015) \\
\hline & Tequila & A. tequilana var. azul & $\begin{array}{l}\text { Alcohols, esters, aldehydes, } \\
\text { furans, terpenes, acids, } \\
\text { hydrocarbures }\end{array}$ & $\begin{array}{l}\text { Prado-Ramírez et al. (2005) } \\
\text { Ceballos-Magaña et al. (2013) } \\
\text { Prado-Jaramillo et al. (2015) }\end{array}$ \\
\hline \multirow[t]{2}{*}{ Aging } & Tequila & A. tequilana var. azul & $\begin{array}{l}\text { Acetals, terpenes, aldehydes, } \\
\text { esters, ketones, furans phenols, } \\
\text { acids, hydrocarburs, alcohols }\end{array}$ & $\begin{array}{l}\text { López-Ramírez et al. (2013) } \\
\text { Ceballos-Magaña et al. (2013 } \\
\text { Prado-Jaramillo et al. (2015) } \\
\text { González-Robles and Cook } \\
\text { (2016) }\end{array}$ \\
\hline & $\begin{array}{l}\text { Tequila, } \\
\text { Mezcal }\end{array}$ & $\begin{array}{l}\text { A. tequilana var. azul } \\
\text { A. angustifolia }\end{array}$ & Furans & Muñoz-Muñoz et al. (2009) \\
\hline
\end{tabular}




\section{Figure Captions}

Fig 16.1 The key role of Saccharomyces cerevisiae in production of fermented beverages. Adapted from Walker and Stewart (2016)

Fig 16. 2 Categories of the main global whiskies. Adapted from Walker and Hill (2016)

Fig 16.3 Summary of the main processes involved in Scotch malt whisky production. Adapted from Walker and Hill (2016)

Fig 16.4 Mezcal elaboration process.
(a) Agave angustifolia
(b) Raw agave heads or piñas
(c) it oven filed with stones
(d) Brick oven
(e) Cooked agave heads or piñas
(f) Rudimentary mill or tahona
(g) Fermentation of cooked agave must with fiber in wooden vats
(h) Fermentation of agave must without fiber in a brick tank
(i) Distillation of fermented agave must in a rudimentary still
(j) Arab type still
(k) Mezcal aging in oak barrels (optional)

Figure 16.5 Cognac aroma depicting the cycles of the seasons From: http://www.bnic.fr/cognac/ @ BNIC / Gérard MARTRON 
Fig 16.1

Raw Materials

(Cereals, Sugar Cane, Molasses, Fruit, Agave, Whey, etc.)

Fermentable Sugars

(Maltose, Maltotriose, Sucrose, Fructose, Glucose)

Maturation

Fermentation

S. cerevisiae

(e.g., Beer, Wine, Cider, Mead)

Distillation

Matured Spirits Non-Matured Spirits

(e.g., Whisky, Cognac, Rum)

$\begin{array}{cc}\text { Non-Flavoured } & \text { Flavoured } \\ \text { (e.g., Vodka, Grappa, Tsiporo) } & \text { (e.g., Gin) }\end{array}$


Fig 16.2

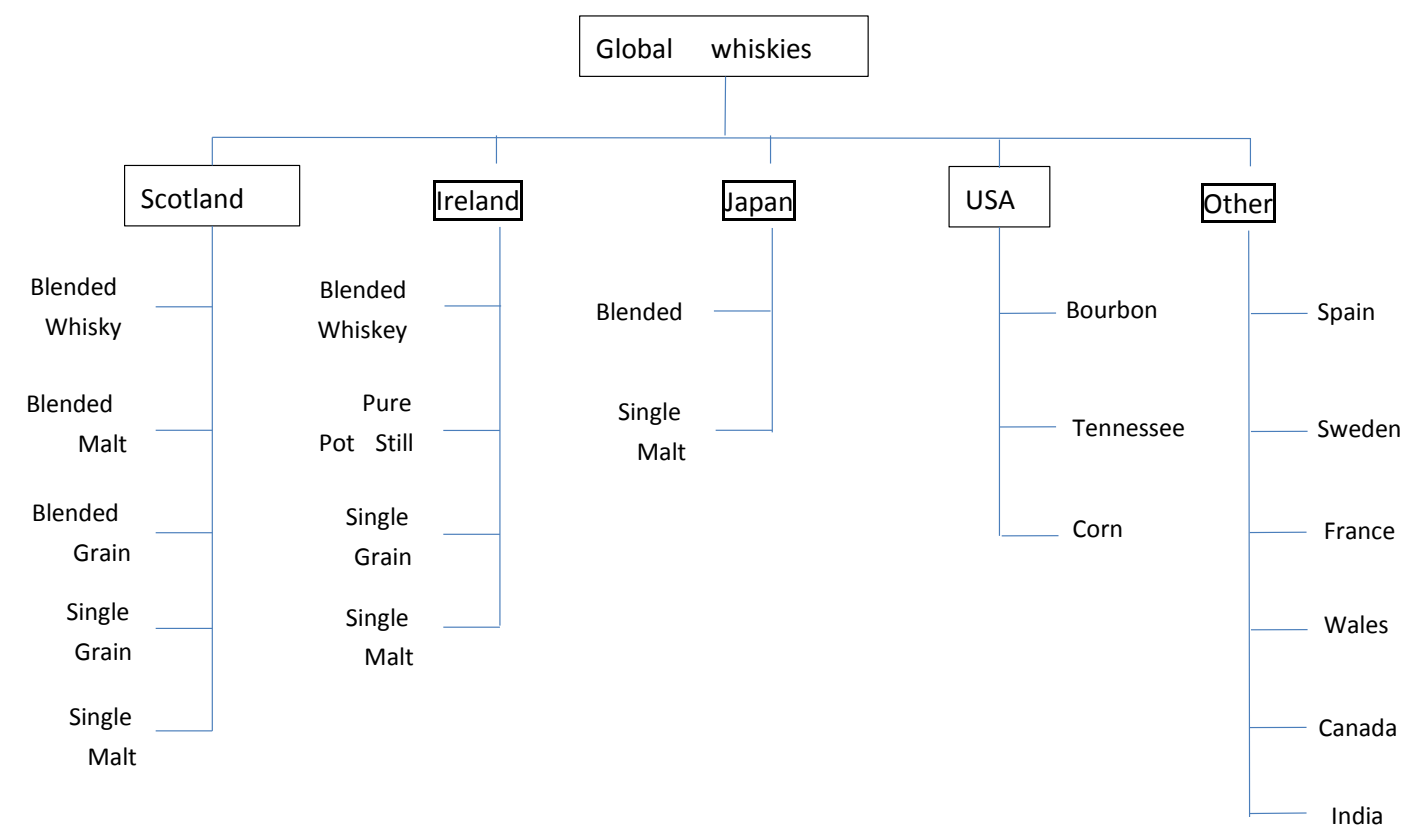


Fig 16.3

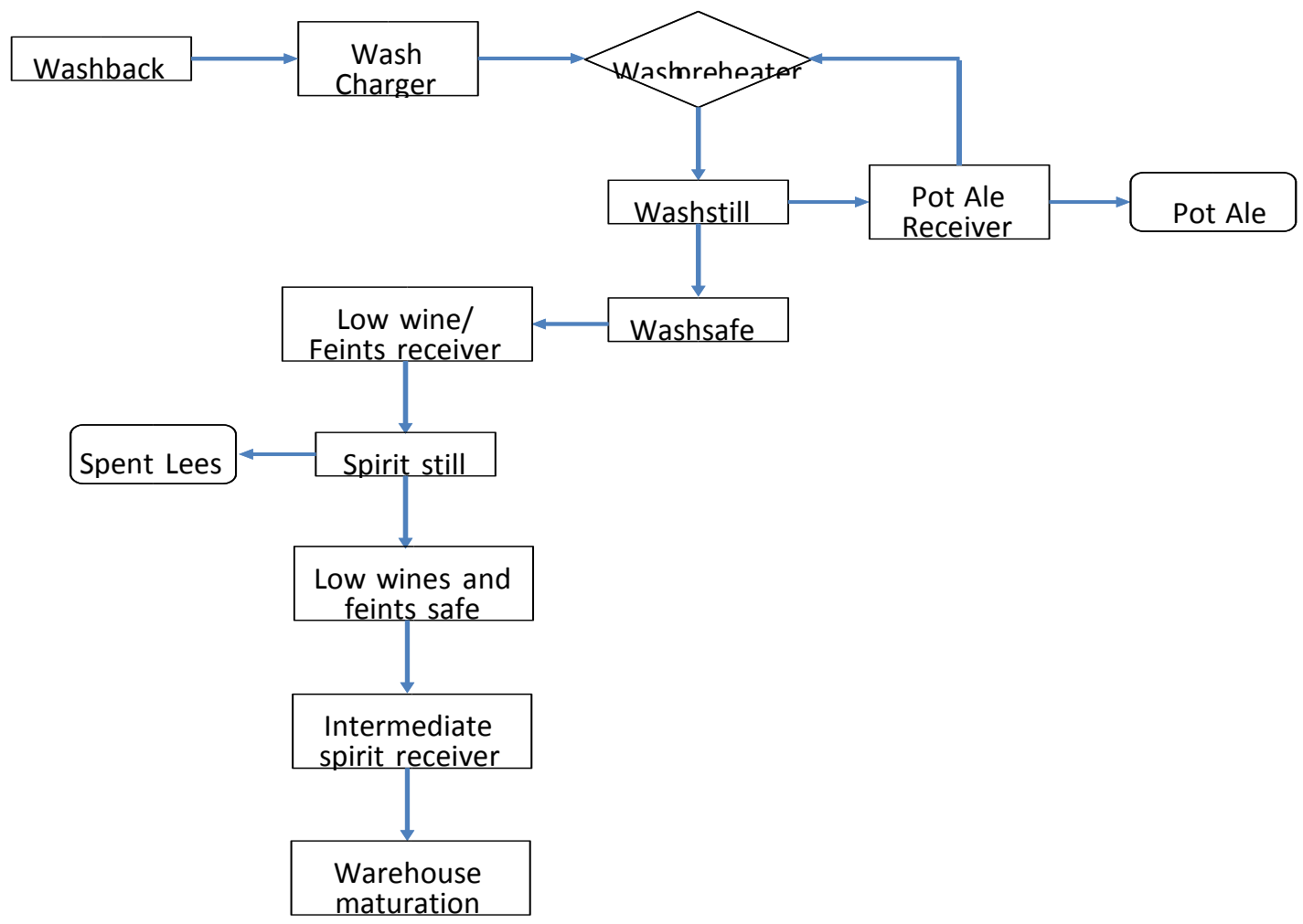




\section{The Cognac Aroma Wheel}

- Principal aromatic notes

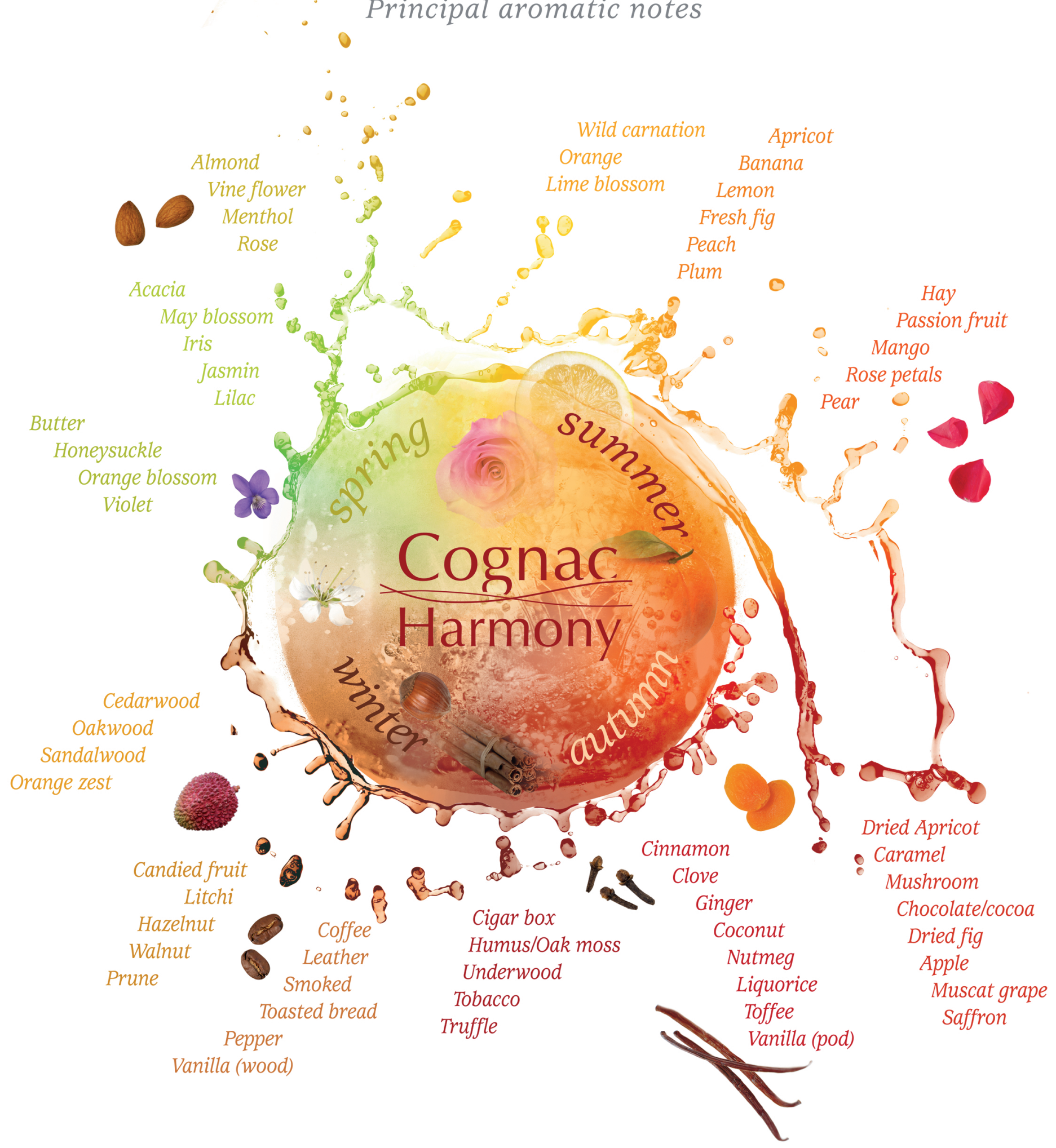

Cognac's palette fits the seasonal cycle perfectly, symbolizing its aromatic wealth. 


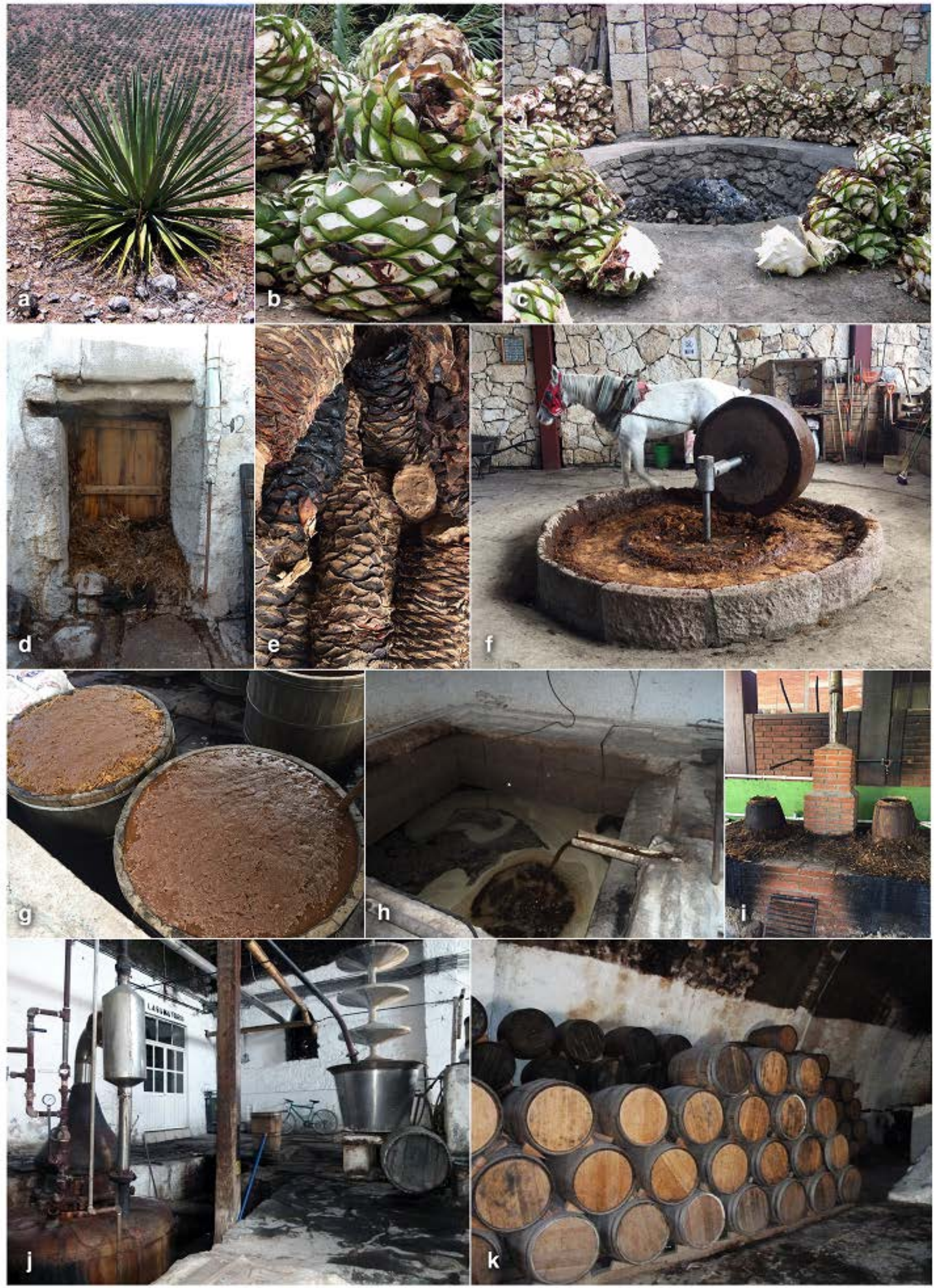

